Review

\title{
Origin of Mélanges of the Franciscan Complex, Diablo Range and Northern California: An Analysis and Review
}

\author{
Loren A. Raymond ${ }^{1,2}$ \\ 1 Geology Department, Sonoma State University, 1801 East Cotati Ave, Rohnert Park, CA 94928, USA; \\ raymondla@bellsouth.net \\ 2 Coast Range Geological Mapping Institute, 3327 Cypress Way, Santa Rosa, CA 95405, USA
}

Received: 5 July 2019; Accepted: 22 July 2019; Published: 1 August 2019

\begin{abstract}
The Franciscan Complex of California is characterized in part by the presence of mélanges. In general, mélange origins are attributed to sedimentary, tectonic, or diapiric processes-or a combination of these. Published reviews list the main features of mélanges characteristic of each type of origin. In this review, particular diagnostic features typical of sedimentary, tectonic, and diapiric mélanges are used to assess 15 specific mélanges, which in some cases have been interpreted in contrasting ways in the literature. The data do not support the view that most Franciscan mélanges were formed by sedimentary processes, but rather that both tectonic and sedimentary processes are important. There is little evidence that diapirism contributed significantly to Franciscan mélange genesis. Tectonic features present in most mélanges of subduction accretionary complexes create challenges in assessing mélange-forming processes. Notably, although tectonic overprints commonly mask the primary diagnostic fabric of sedimentary mélanges, some diagnostic features—such as depositional contacts, fossils in mélange matrix, and interlayering of mélange and non-mélange units-are critical to recognition of mélanges of sedimentary origin.
\end{abstract}

Keywords: mélange; olistostrome; Franciscan Complex

\section{Introduction}

The Franciscan Complex of California and southwestern Oregon (Figure 1) is widely considered to be the archetypal subduction accretionary complex [1-3]. Notable among its attributes are blocks and large masses of blueschist facies rocks, large masses of submarine fan sediments, blocks with ocean plate stratigraphy (OPS), and mélanges. Understanding Franciscan mélanges is central to understanding both the architecture of the Complex and its history, yet the mélanges have been the focal point of several controversies that cloud the architectural analysis.

The definitions, the character, and the origins of Franciscan and other mélanges have all been controversial [2-20]. Mélange definitions vary, but one of four prominent definitions is commonly selected as the basis for mélange discussions, specifically that of Hsu [16,17], Raymond ([21], and Raymond's definition in [5]), Silver and Beutner [22], or Cowan [13]. All agree that mélanges are characterized by a block-in-matrix structure. Long ago, Hsu [16] posited that fragmentation of rocks and mixing of different rock types were the critical processes in formation of these block-in-matrix structures. These now are known to form via tectonic, sedimentary, and diapiric processes [23-25]. Yet, whether or not mélanges must be mappable, must contain exotic blocks, or only form via tectonic processes have been major issues of controversy with regard to both character and to classification. The issues of definition, classification, composition, structure, and origin are reviewed elsewhere [2,15,19,21,26,27], but for the purposes of this paper, the definition of mélange used is that of Raymond [21]: a mélange 
is "a body of rock mappable at a scale of 1:24,000 [or 1:25,000] or smaller and characterized both by the lack of internal continuity of contacts or strata and by the inclusion of fragments and blocks of all sizes, both exotic and native, embedded in a fragmented matrix of finer-grained material." This definition serves as the basis for the discussion below and clarifies some fundamentals of structure and composition as I use them here. Note that this mélange definition requires both mappability and exotic blocks but does not specify mode of origin. Exotic blocks are here considered to be "variably sized masses of rock occurring in a lithologic association foreign to that in which the mass formed" [5,19]. Clearly, as used here, the term mélange refers neither to fabrics and structures nor to all block-in-matrix units (e.g., compare $[18,21]$ with [13]). Specifically, the definition excludes dismembered formations from the mélange category of rock units [19,21].

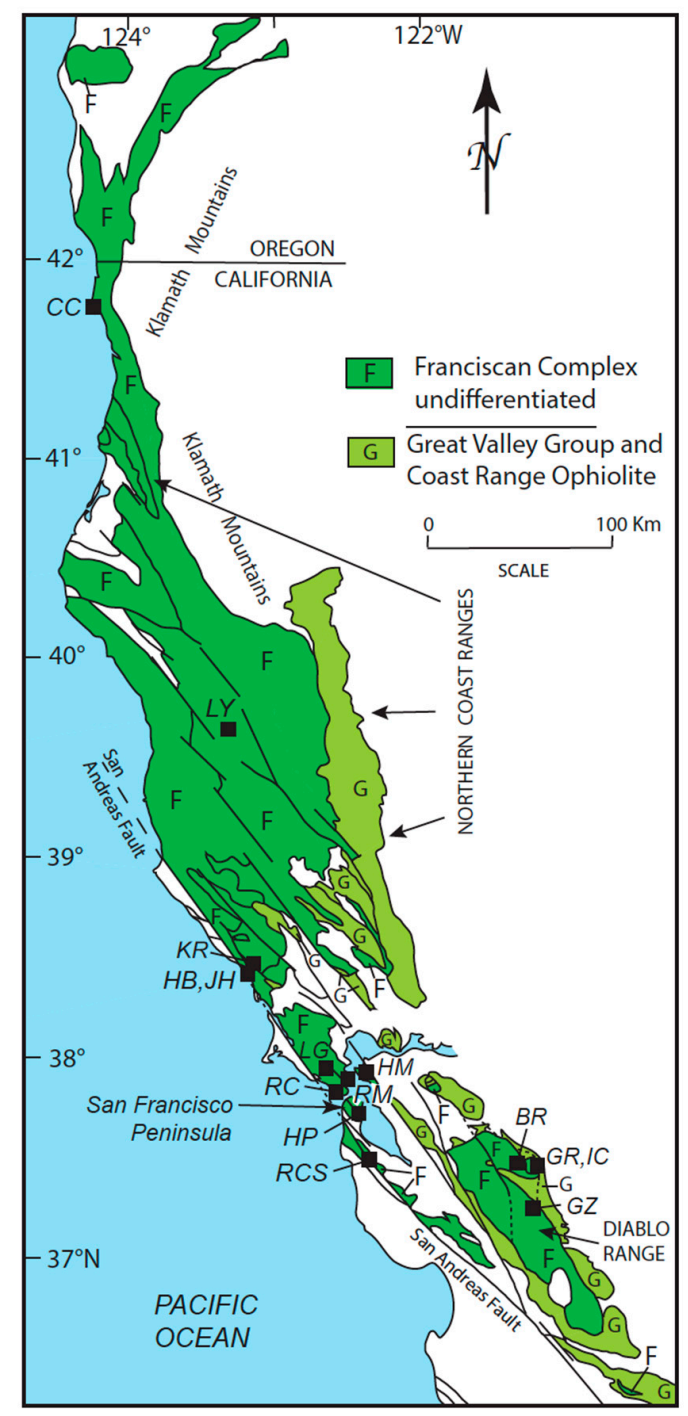

Figure 1. Generalized map of the Franciscan Complex of Oregon and the Northern Coast Ranges and Diablo Range of California, showing the general distribution of Franciscan rocks and the locations of exposures of mélanges described in the text. From north to south the mélanges are $\mathrm{CC}=\mathrm{Crescent}$ City Olistostrome, LY = Laytonville Mélange, KR = King Ridge Road Mélange, HB = Heavens Beach Mélange, JH = Jenner Headlands Mélange, LG = Liberty Gulch Mélange, HM = Hillside Mélange of El Cerrito, RC = Rodeo Cove Mélange, RM = Ring Mountain Mélange, HP = Hunters Point Mélange, RCS = the Serpentinite Mélange of Redwood City, BR = Blue Rock Springs Mélange, GR = Gerber Ranch Mélange, IC = Ingram Creek Mélange, and GZ = the Garzas Mélange. 
Given the definitions set out above, the primary purpose of this paper is to review the characteristics of several relatively well-described Franciscan mélanges and relate the descriptive features to the proposed origins of the mélanges. Specifically, I discuss the origins of individual Franciscan mélanges viewed in the light of the composite set of published criteria for each type of mélange origin, and I add new descriptive material on selected mélanges. This review focuses attention on some conflicting interpretations of available data and on the contrasting emphases placed on particular criteria in determining the origins of particular Franciscan mélanges. In addition, this study documents the fact that, rather than being largely sedimentary in origin, Franciscan mélanges have formed by both tectonic and sedimentary processes.

\section{Distinguishing Sedimentary, Diapiric, and Tectonic Mélanges}

Over several decades, various workers have set out criteria for distinguishing sedimentary, diapiric, and tectonic mélanges from one another ([2,13,15,21,25,27-29] and Figure 20.2 of [29]). Table 1 presents a composite set of criteria based primarily on the work of Raymond [2] and Festa et al. [27]. These criteria include compositional, structural, and spatial aspects of mélanges formed in various ways.

Among the criteria characteristic of mélanges formed via the various processes are several features developed via more than one process plus a few definitive features particularly indicative of each formative process (Table 1). Mélange origins are clearly linked to the processes of fragmentation and mixing. For mélanges of deformational origin in which fragmentation and mixing is primarily a tectonic process (tectonic mélanges), the most definitive features are sheared or deformed contacts, the presence of S-C and P-R fabrics, and the presence of a pervasive scaly microfabric that may or may not be accompanied by microbreccia, pseudotachylite, or both (Table 1). In contrast, a sedimentary origin is particularly signaled by depositional or gradational contacts with sedimentary units, interbedding with sedimentary units, well rounded mesoscopic clasts and microscopic grains of diverse rock types, and in situ fossils in the mélange matrix (Table 1). Inasmuch as rounding of clasts may result from sedimentary, tectonic, diapiric flow, or a combination of weathering and other processes [30-32], it is important that rounded clasts be of diverse compositions to eliminate some of the alternative tectonic, diapiric, and weathering causes of rounding from consideration as formative processes. Mélanges formed via diapirism are best indicated by elliptical to circular zoned map patterns and mélange core zones with randomly oriented clasts plus marginal zones with steeply inclined fabrics (Table 1). Many mélanges are polygenetic, having formed via one process and subsequently experienced additional fragmentation and mixing via another. Sedimentary mélanges are notably imprinted with post-depositional tectonic deformation features. 
Table 1. Comparison of features and origins of selected Franciscan mélanges.

\begin{tabular}{|c|c|c|c|c|c|c|c|c|c|c|c|c|c|c|c|}
\hline $\begin{array}{ll}\text { Criteria }^{a} & \text { Mélange -> }\end{array}$ & $\begin{array}{l}\text { Crescent City } \\
\text { Olistostrome }\end{array}$ & Laytonville & $\begin{array}{l}\begin{array}{l}\text { King Ridge } \\
\text { Road }\end{array} \\
\text {. }\end{array}$ & $\begin{array}{l}\text { Liberty } \\
\text { Gulch }\end{array}$ & Hillside & $\begin{array}{c}\text { Blue Rock } \\
\text { Springs }\end{array}$ & Garzas & $\begin{array}{l}\begin{array}{l}\text { Ingram } \\
\text { Canyon }\end{array} \\
\text { C. }\end{array}$ & Gerber Ranch & $\begin{array}{l}\text { Rodeo } \\
\text { Cove }\end{array}$ & $\begin{array}{c}\text { Jenner } \\
\text { Headlands }\end{array}$ & $\begin{array}{c}\text { Hunters } \\
\text { Point }\end{array}$ & $\begin{array}{c}\text { Ring } \\
\text { Mountain }\end{array}$ & $\begin{array}{c}\text { Redwood } \\
\text { City }\end{array}$ & $\begin{array}{l}\begin{array}{l}\text { Heaven's } \\
\text { Beach }\end{array} \\
\text { (a) }\end{array}$ \\
\hline $\begin{array}{l}\text { Author Proposed Formation } \\
\text { Mechanism }{ }^{b}\end{array}$ & $\mathrm{~s}$ & $\mathrm{~s}$ & $\mathrm{~s}$ & $\mathrm{~s}$ & $\mathrm{~s}$ & $\mathrm{~s}$ & $\mathrm{~T}$ & $\mathrm{~T}$ & $\mathrm{~T}$ & $\mathrm{~T}$ & $\mathrm{~T}$ & $\mathrm{~T}$ & $\mathrm{~S}, \mathrm{~T}$ & $\mathrm{D}$ & $\mathrm{P}(\mathrm{S}, \mathrm{T})$ \\
\hline \multicolumn{16}{|c|}{ Sedimentary Mélánges } \\
\hline Irregular to tabular in map view & $\sqrt{ }$ & $\checkmark$ & $\sqrt{ }$ & $\sqrt{ }$ & $\sqrt{ }$ & $\sqrt{ }$ & $\sqrt{ }$ & $\sqrt{ }$ & $\sqrt{ }$ & $\sqrt{ }$ & $\sqrt{ }$ & $\sqrt{ }$ & $\sqrt{ }$ & $\sqrt{ }$ & $\sqrt{ }$ \\
\hline $\begin{array}{l}\text { Lenticular to tabular shape in section } \\
\text { Depositional to gradational contacts c }\end{array}$ & $\sqrt{1}$ & $\frac{1}{1}$ & $\frac{1}{1}$ & $\sqrt{1}$ & $\sqrt{1}$ & $\sqrt{ }$ & $\sqrt{ }$ & $\sqrt{ }$ & $\sqrt{ }$ & $\sqrt{ }$ & $\sqrt{ }$ & $\sqrt{ }$ & $\sqrt{ }$ & $\sqrt{ }$ & $\mathrm{v}$ \\
\hline $\begin{array}{l}\text { Depositional to gradational contacts" } \\
\text { Irregular to sub-parallel stratigraphic }\end{array}$ & $\mathrm{v}$ & $\frac{d}{d}$ & Possibly & $\begin{array}{l}\mathrm{v} \\
\mathrm{v}\end{array}$ & $\begin{array}{c}\mathrm{v} \\
\end{array}$ & & & & & & & & & & \\
\hline boundaries & $\mathrm{v}$ & $\mathrm{v}$ & & $\mathrm{v}$ & $\mathrm{v}$ & $\mathrm{v}$ & & & & & & & & & \\
\hline Interbedded with stratigraphic layers & $\sqrt{ }$ & $\sqrt{ }$ & & $\sqrt{ }$ & & $\sqrt{ }$ & $\sqrt{ }$ & & & & & & & & \\
\hline Highly disordered isotropic fabric & $\checkmark$, in some & & $\sqrt{ }$ & $\checkmark$, In part & $\begin{array}{l}\text { Locally in } \\
\text { enclaves }\end{array}$ & & & & & & & & & & $\begin{array}{l}\begin{array}{l}\text { Only in } \\
\text { blocks }\end{array} \\
\text { bes }\end{array}$ \\
\hline $\begin{array}{l}\text { Matrix }=\text { mudrock }(\mathrm{m}) \text {, Sandstone }(\mathrm{s}), \\
\text { metabasites }(\mathrm{b}) \text {, Serpentinite }(\mathrm{u})\end{array}$ & $\sqrt{ }(\mathrm{m})$ & $\sqrt{ }(m, s)$ & $\sqrt{ }(\mathrm{s})$ & $\sqrt{ }(\mathrm{m})$ & $\sqrt{ }(m, s)$ & $\sqrt{ }(\mathrm{m})$ & $\sqrt{ }(\mathrm{m} \pm \mathrm{s})$ & $\sqrt{ }(\mathrm{m})$ & $\sqrt{ }(\mathrm{m}, \mathrm{u})$ & $\sqrt{ }(b, m, s)$ & $\sqrt{ }(\mathrm{u})$ & $\sqrt{ }(\mathrm{m}, \mathrm{u})$ & $\sqrt{ }(\mathrm{u})$ & $\sqrt{ }(\mathrm{u})$ & $\sqrt{ }(\mathrm{m}, \mathrm{s})$ \\
\hline Weak scaly cleavage at base & & $\sqrt{1}$ & & & $\sqrt{ }$ & & & & & & & & & & \\
\hline Clast composition diverse & $\sqrt{ }$ & $\sqrt{4}$ & $\mathrm{~d}$ & $\sqrt{1}$ & Not very & $\sqrt{ }$ & $\mathrm{d}$ & $\sqrt{ }$ & $\checkmark$ & Not very & $\sqrt{ }$ & Not very & $\sqrt{ }$ & & $\sqrt{ }$ \\
\hline Native and exotic blocks & $\sqrt{1}$ & $\sqrt{1}$ & $\sqrt{1}$ & $\sqrt{ }$ & $\sqrt{ }$ & $\frac{1}{4}$ & $\frac{1}{4}$ & $\sqrt{1}$ & $\frac{1}{4}$ & $\sqrt{ }$ & $\sqrt{ }$ & $\sqrt{ }$ & $\sqrt{1}$ & $\sqrt{ }$ & $\sqrt{1}$ \\
\hline Block size $<1 \mathrm{~m}->1 \mathrm{~km}$ & v & $\sqrt{ }$ & $\sqrt{2}$ & $\sqrt{\text {, small }}$ & $\sqrt{\text {, small }}$ & $\sqrt{ }$ & $\sqrt{ }$ & $\sqrt{ }$ & $\sqrt{ }$ & $\sqrt{ }$ & $\checkmark$ & $\sqrt{ }$ & $\checkmark$ & $\mathrm{v}$ & $\sqrt{ }$ \\
\hline $\begin{array}{l}\text { Blocks rounded, irregular, angular, or } \\
\text { tabular }\end{array}$ & $\sqrt{ }$ & $\checkmark$ & $\sqrt{ }$ & $\sqrt{ }$ & $\sqrt{ }$ & $\sqrt{ }$ & $\sqrt{ }$ & $\sqrt{ }$ & $\sqrt{ }$ & $\sqrt{ }$ & $\sqrt{ }$ & $\sqrt{ }$ & $\sqrt{ }$ & $\sqrt{ }$ & $\sqrt{ }$ \\
\hline $\begin{array}{l}\text { Well rounded clasts of various rock } \\
\text { types }\end{array}$ & $\sqrt{ }$ & & & $\sqrt{ }$ & $\sqrt{ }$ & $\sqrt{ }$ & & & & & & & $\sqrt{ }$ & & $\sqrt{ }$ \\
\hline $\begin{array}{l}\text { Block margins sharp to diffuse with soft } \\
\text { sediment deformation features }\end{array}$ & $\mathrm{v}$ & Locally & & & & & & & & & & & & & \\
\hline Fossils in matrix & & & & & & & & & & & & & & & \\
\hline Number of the 15 features matched & $\begin{array}{c}13(3 \text { of } 4 \\
\text { major) }\end{array}$ & $\begin{array}{c:}12(2 \text { of } 4 \\
\text { major) }\end{array}$ & $\begin{array}{l}9 \text { (1 of } 4 \text { major }) \\
\end{array}$ & $\begin{array}{l}12(3 \text { of } 4 \\
\text { major })\end{array}$ & $\begin{array}{l}11(3 \text { of } 4 \\
\text { major })\end{array}$ & $\begin{array}{l}10(2 \text { of } 4 \\
\text { major) }\end{array}$ & $\begin{array}{l}8(1 \text { of } 4 \\
\text { major })\end{array}$ & $\begin{array}{c}7(0 \text { of } 4 \\
\text { major })\end{array}$ & 7 ( 0 of 4 major $)$ & $\begin{array}{c}6(0 \text { of } 4 \\
\text { major })\end{array}$ & $\begin{array}{l}7(0 \text { of } 4 \\
\text { major })\end{array}$ & $\begin{array}{c}6(0 \text { of } 4 \\
\text { major })\end{array}$ & $\begin{array}{l}8(1 \text { of } 4 \\
\text { major })\end{array}$ & $\begin{array}{c}6(0 \text { of } 4 \\
\text { major })\end{array}$ & $\begin{array}{c}8(1 \text { of } 4 \\
\text { major })\end{array}$ \\
\hline & & & & & & Tectonic Mélan & & & & & & & & & \\
\hline $\begin{array}{l}\text { lolongate to lenticular or irregular map } \\
\text { shape }\end{array}$ & $\sqrt{ }$ & $\sqrt{ }$ & $\sqrt{ }$ & $\sqrt{ }$ & $\sqrt{ }$ & $\sqrt{ }$ & $\sqrt{ }$ & $\sqrt{ }$ & $\sqrt{ }$ & $\sqrt{ }$ & $\sqrt{ }$ & $\sqrt{ }$ & & $\checkmark$ & $\checkmark$ \\
\hline $\begin{array}{l}\text { Wedge to lenticular or tabular shape in } \\
\text { section }\end{array}$ & $\mathrm{v}$ & $\mathrm{v}$ & $\sqrt{ }$ & $\mathrm{v}$ & $\checkmark$ & $\mathrm{v}$ & $\mathrm{v}$ & $\mathrm{v}$ & $\sqrt{ }$ & $\mathrm{v}$ & $\checkmark$ & $\sqrt{ }$ & $\sqrt{ }$ & $\checkmark$ & $\mathrm{v}$ \\
\hline Sheared/deformed contacts & & $\begin{array}{l}\text { Minor } \\
\text { Local }\end{array}$ & Locally & $\begin{array}{l}\text { Minor } \\
\text { Local }\end{array}$ & Locally & $\mathrm{v}$ & $\mathrm{v}$ & $\mathrm{v}$ & $\mathrm{v}$ & $\mathrm{v}$ & $\checkmark$ & $\mathrm{v}$ & $\mathrm{v}$ & $\checkmark$ & $\checkmark$ \\
\hline $\begin{array}{l}\text { Structurally ordered block-in-matrix } \\
\text { (anisotropic) fabric }\end{array}$ & $\sqrt{ }$, in part & $\sqrt{ }$ & & & Locally & $\sqrt{ }$ & $\mathrm{v}$ & $\mathrm{v}$ & $\sqrt{ }$ & $\mathrm{v}$ & $\sqrt{ }$ & $\sqrt{ }$ & $\sqrt{ }$ & Locally & $\checkmark$ \\
\hline $\begin{array}{l}\text { Matrix composition mudrock, mudrock + } \\
\text { sandstone, or serpentinite }\end{array}$ & $\sqrt{ }$ & $\sqrt{ }$ & $\sqrt{ }$ & $\sqrt{ }$ & $\sqrt{ }$ & $\sqrt{ }$ & $\sqrt{ }$ & $\sqrt{ }$ & $\sqrt{ }$ & $\sqrt{ }$ & $\sqrt{ }$ & $\sqrt{ }$ & $\sqrt{ }$ & $\sqrt{ }$ & $\sqrt{ }$ \\
\hline Block com & $\checkmark$ & $\checkmark$ & $\checkmark$ & $\checkmark$ & $\sqrt{ }$ & $\checkmark$ & $\checkmark$ & $\mathrm{v}$ & $\mathrm{v}$ & $\mathrm{v}$ & $\checkmark$ & $\checkmark$ & $\checkmark$ & Slightly & $\sqrt{ }$ \\
\hline Native and exotic blocks & $\sqrt{ }$ & $\sqrt{ }$ & $\sqrt{v}$ & $\sqrt{ }$ & $\sqrt{ }$ & $\sqrt{ }$ & $\sqrt{ }$ & $\sqrt{ }$ & $\sqrt{ }$ & $\sqrt{v}$ & $\checkmark$ & $\sqrt{ }$ & $\sqrt{ }$ & $y$ & $\sqrt{ }$ \\
\hline $\begin{array}{l}\text { Facoidal, sigmoidal, tabular, to lenticular } \\
\text { blocks }\end{array}$ & $\sqrt{ }$ & & & Some & Common & $\sqrt{ }$ & $\sqrt{ }$ & $\sqrt{ }$ & $\sqrt{ }$ & $\sqrt{ }$ & $\sqrt{ }$ & $\sqrt{ }$ & $\sqrt{ }$ & Locally & $\sqrt{ }$ \\
\hline Blocks $=<1 \mathrm{~m}->1 \mathrm{~km}$ & $\mathrm{v}$ & $\mathrm{v}$ & $\mathrm{v}$ & $\mathrm{v}$ & $\checkmark$ & $\mathrm{v}$ & $\mathrm{v}$ & $\mathrm{v}$ & $\mathrm{v}$ & $\mathrm{v}$ & $\mathrm{v}$ & $\mathrm{v}$ & $\mathrm{v}$ & $\mathrm{v}$ & $\mathrm{v}$ \\
\hline $\begin{array}{l}\text { Microfabric scaly } \pm \text { microbreccia and } \\
\text { pseudotachylite }\end{array}$ & $\checkmark$ & $\sqrt{ }$ & & & $\begin{array}{l}\text { In black } \\
\text { rock zone } \\
\text { at top of } \\
\text { melange }\end{array}$ & $\checkmark$ & $\sqrt{ }$ & $\sqrt{ }$ & $\sqrt{ }$ & $\sqrt{ }$ & $\sqrt{ }$ & $\sqrt{ }$ & $\sqrt{ }$ & Locally & In part \\
\hline Anastamosing shears and microshears & $\sqrt{ }$ & $\sqrt{ }$ & & Locally & Locally & $\sqrt{ }$ & $\sqrt{ }$ & $\sqrt{ }$ & $\sqrt{ }$ & $\sqrt{ }$ & $\sqrt{ }$ & $\sqrt{ }$ & $\sqrt{ }$ & Locally & $\sqrt{ }$ \\
\hline
\end{tabular}


Table 1. Cont.

\begin{tabular}{|c|c|c|c|c|c|c|c|c|c|c|c|c|c|c|c|}
\hline $\begin{array}{ll}\text { Criteria }^{a} & \text { Mélange } \rightarrow> \\
\end{array}$ & \begin{tabular}{|l|} 
Crescent City \\
Olistostrome \\
\end{tabular} & Laytonville & $\begin{array}{c}\text { King Ridge } \\
\text { Road }\end{array}$ & $\begin{array}{l}\text { Liberty } \\
\text { Gulch }\end{array}$ & Hillside & $\begin{array}{c}\text { Blue Rock } \\
\text { Springs }\end{array}$ & Garzas & \begin{tabular}{|l} 
Ingram \\
Canyon
\end{tabular} & Gerber Ranch & $\begin{array}{l}\text { Rodeo } \\
\text { Cove }\end{array}$ & $\begin{array}{l}\text { Jenner } \\
\text { Headlands } \\
\end{array}$ & $\begin{array}{c}\text { Hunters } \\
\text { Point }\end{array}$ & $\begin{array}{c}\text { Ring } \\
\text { Mountain } \\
\end{array}$ & $\begin{array}{c}\text { Redwood } \\
\text { City }\end{array}$ & $\begin{array}{c}\text { Heaven's } \\
\text { Beach }\end{array}$ \\
\hline S-C, P-R fabrics & & & & & & & $\checkmark$ & $\checkmark$ & & $v$ & & & & & \\
\hline Boudinage common & $\sqrt{ }$ & $\sqrt{ }$ & & & $\sqrt{ }$ & & & $\sqrt{ }$ & $\sqrt{ }$ & $\sqrt{ }$ & $\sqrt{ }$ & & & & $\sqrt{ }$ \\
\hline Folds common & Slump folds & $\begin{array}{c}\text { In some } \\
\text { blocks and } \\
\text { matrix }\end{array}$ & In some blocks & & $\sqrt{ }$ & $\begin{array}{c}\text { Overprint/ } \\
\text { Cenozoic folds }\end{array}$ & & In blocks & $\begin{array}{l}\text { In some blocks } \\
\text { and matrix }\end{array}$ & In veins & & & In blocks & & \\
\hline $\begin{array}{l}\text { Striations common } \\
\text { Veins common }\end{array}$ & Mudrock & & & & & & & $\frac{1}{1}$ & $\frac{1}{1}$ & $y$ & $\begin{array}{l}y \\
\frac{1}{2}\end{array}$ & & $\frac{1}{1}$ & $y$ & $\sqrt{ }$ \\
\hline Number of the 16 features matched & $\begin{array}{l}13(1 \text { of } 3 \\
\text { major })\end{array}$ & $\begin{array}{c}11(1 \text { of } 3 \\
\text { major) }\end{array}$ & 8 (1 of 3 major $)$ & $\begin{array}{l}8(0 \text { of } 3 \\
\text { major })\end{array}$ & $\begin{array}{l}13 \text { (2 of } 3 \\
\text { major) }\end{array}$ & $\begin{array}{l}11(2 \text { of } 3 \\
\text { major) }\end{array}$ & $\begin{array}{c}12(3 \text { of } 3 \\
\text { major })\end{array}$ & $\begin{array}{l}15(3 \text { of } 3 \\
\text { major) }\end{array}$ & $\begin{array}{l}15(2 \text { of } 3 \\
\text { major) }\end{array}$ & $\begin{array}{l}14(3 \text { of } 3 \\
\text { major })\end{array}$ & $\begin{array}{l}14(2 \text { of } 3 \\
\text { major) }\end{array}$ & $\begin{array}{l}11(2 \text { of } 3 \\
\text { major) }\end{array}$ & $\begin{array}{c}14(3 \text { of } 3 \\
\text { major })\end{array}$ & $\begin{array}{c}12(3 \text { of } 3 \\
\text { major })\end{array}$ & $\begin{array}{c}13(2 \text { of } 3 \\
\text { major })\end{array}$ \\
\hline & & & & & & Diapiric Mélan & & & & & & & & & \\
\hline $\begin{array}{l}\text { Internal structural zoning of body from } \\
\text { anisotropic to isotropic }\end{array}$ & & & & & & & & & & & & & & & \\
\hline $\begin{array}{l}\text { Circular to elliptical on maps; } \\
\text { commonly zoned }\end{array}$ & & & & & & & & & & & & & $\sqrt{ }$ & & \\
\hline Section conical to cylindrical & & & & & & & & & & & & & & & \\
\hline $\begin{array}{l}\text { High angle discordant to conformable } \\
\text { contacts }\end{array}$ & $\checkmark$ & $\checkmark$ & $\sqrt{ }$ & $\checkmark$ & $\checkmark$ & $\mathrm{v}$ & $\mathrm{v}$ & $\sqrt{ }$ & $\sqrt{ }$ & $\checkmark$ & $\mathrm{v}$ & $\checkmark$ & $\mathrm{v}$ & $\checkmark$ & $\checkmark$ \\
\hline $\begin{array}{l}\text { Deformation zoned with core } \\
\text { noncylindrical folds and rim scaly fabric }\end{array}$ & & & & & & & & & & & & & & & \\
\hline Native and exotic blocks & $\checkmark$ & $\checkmark$ & $\checkmark$ & $\checkmark$ & $\sqrt{ }$ & $\checkmark$ & $\checkmark$ & $\sqrt{ }$ & $\sqrt{ }$ & $\sqrt{ }$ & $\checkmark$ & $\checkmark$ & $\mathrm{v}$ & $\checkmark$ & $\checkmark$ \\
\hline $\begin{array}{l}\text { Blocks irregular in core; phacoidal blocks } \\
\text { in rim }\end{array}$ & & & & & & & & & & & & & & & \\
\hline Blocks $=<1 \mathrm{~m}-15+\mathrm{m}$; smaller in rim zone & & & & & & & & & & & & & & & \\
\hline $\begin{array}{l}\text { Block composition variable, but } \\
\text { sandstone common and serpentinite } \\
\text { possible }\end{array}$ & $\sqrt{ }$ & $\sqrt{ }$ & & $\sqrt{ }$ & $\sqrt{ }$ & $\sqrt{ }$ & $\sqrt{ }$ & $\sqrt{ }$ & $\sqrt{ }$ & $\sqrt{ }$ & & $\sqrt{ }$ & & $\begin{array}{l}\text { No-Mainly } \\
\text { Serpentin-ite }\end{array}$ & $\sqrt{ }$ \\
\hline Clasts randomly oriented in core zone & & & & & & & & & & & & & & & \\
\hline $\begin{array}{l}\text { Marginal zone has aligned elongated } \\
\text { clasts }\end{array}$ & & & & & & & & & & & & & & & \\
\hline S-C fabric in marginal zone & & & & & & & & & & & & & & & \\
\hline $\begin{array}{l}\text { Sub-vertical microfabric in Matrix } \\
\text { relative to nearby sedimentary layers }\end{array}$ & & & & & & & & & & & & & & & \\
\hline Number of the 13 features matched & $3(0$ of 4 major $)$ & $\begin{array}{l}3(0 \text { of } 4 \\
\text { major })\end{array}$ & $2(0$ of 4 major $)$ & $\begin{array}{c}3(0 \text { of } 4 \\
\text { major })\end{array}$ & $\begin{array}{c}3(0 \text { of } 4 \\
\text { major })\end{array}$ & 3 ( 0 of 4 major $)$ & $\begin{array}{l}3(0 \text { of } 4 \\
\text { major })\end{array}$ & $\begin{array}{l}3(0 \text { of } 4 \\
\text { major })\end{array}$ & $3(0$ of 4 major $)$ & $\begin{array}{c}3(0 \text { of } 4 \\
\text { major })\end{array}$ & $\begin{array}{l}2(0 \text { of } 4 \\
\text { major) }\end{array}$ & $\begin{array}{c}3(0 \text { of } 4 \\
\text { major })\end{array}$ & $\begin{array}{l}3(1 \text { of } 4 \\
\text { major) }\end{array}$ & $\begin{array}{c}2(0 \text { of } 4 \\
\text { major })\end{array}$ & $\begin{array}{l}3(0 \text { of } 4 \\
\text { major })\end{array}$ \\
\hline Sources & {$[6,34-38]$} & {$[28,39,40]$} & [41] & {$[32,42]$} & $\begin{array}{c}{[20,42-} \\
44]\end{array}$ & {$[2,45]$} & $\begin{array}{ll}{[2,11,42,} \\
46-49]\end{array}$ & {$[2,45-48]$} & {$[2,45,48]$} & {$[23,50,51]$} & {$[7,52,53]$} & [54] & {$[3,55,56]$} & [57] & {$[3,32]$} \\
\hline
\end{tabular}

a_Criteria based on references $[2,3,27,33]$ and observations of the author; ${ }^{\mathrm{b}}-\mathrm{S}=$ sedimentary (olistostromal), $\mathrm{D}=$ diapiric, $\mathrm{T}=$ tectonic, $\mathrm{P}=$ polygenetic; $\mathrm{c}-\mathrm{Major}$ definitive criteria are bold face. 


\section{Data from Selected Franciscan Mélanges}

Fifteen of the most well-known, thoroughly studied, or widely distributed mélanges mapped within the Franciscan Complex of northern California and the Diablo Range are selected for review here. The general locations of these mélanges are shown on Figure 1. The selected mélanges have been assigned origins spanning the range of origins noted above. Most of the selected mélanges have been described by a single author or an author and colleagues. In some cases, however, multiple authors have studied a mélange and proposed contrasting origins. For others, I provide alternatives to the proposed origins.

\subsection{Sedimentary Mélanges}

Mélanges that clearly exhibit most of the definitive features of sedimentary mélanges are common in the Franciscan Complex. In some cases, the definitive features indicating an origin are obscured by later tectonism, whereas in others, they are obvious.

\subsubsection{The Crescent City Olistostrome}

The Crescent City Olistostrome, a sedimentary mélange, is exposed along the northern California coast from the vicinity of Pt. St. George south to Crescent City and beyond (CC, Figure 1) [6,34-38]. Multiple exposures, particularly in beach-facing cliffs, clearly reveal the features of the mélange.

In terms of map and cross sectional appearance, the mélange is elongate and lensoidal to tabular ([6], [34] and Figures 2\&8 therein, [37] and Figure 28 therein). In cliff exposures, the Crescent City Olistostrome occurs as an interbedded, tabular layer between two submarine fan facies B sandstone units (fan facies terminology follows Mutti and Ricchi-Lucchi [58]). Stratigraphic boundaries between the mélange unit and enclosing sandstones are depositional, and the contacts of the mélange are parallel to subparallel with contacts within the bounding units (Figure 2A).

Internally, the Crescent City Olistostrome displays a range of fabrics $[6,34,37]$. The matrix is locally sandy mudrock with variable amounts of sand and silt [37] (but note that Aalto, at times, designated the rock as argillite, e.g., [6]). Local areas of isotropic fabric are present, especially in zones of soft sediment deformation and fluidized sediment injection (Figure 2B). Scaly fabric with anastomosing fractures occurs in many exposures. Microbreccia is present locally. Soft sediment deformation features include folds, sandstone dikes, and floating sand masses that take on the appearance of clasts.

Blocks and clasts (olistoliths) in the Crescent City Olistostrome include a variety of native to exotic rock types $[6,37]$ (Table 2). The dominant clasts are "immature sandstone", but ocean plate stratigraphy fragments (OPS fragments, i.e., serpentinite, peridotite, basic volcanic rocks \pm radiolarian chert, radiolarian chert, pelagic limestone, and sandstones) plus phyllite and a range of volcanic and plutonic rocks, such as tonalite and porphyritic dacite, also occur as clasts [6,37]. The bulk of the clasts are sedimentary (sandstones), and the parent rocks likely formed in a submarine fan environment. Most clasts other than the dominant arenite sandstones are exotic. Clasts are angular to subangular but include both primary sub-rounded to rounded forms and secondary rounded to discoidal shapes, the latter where clasts are more deformed [37]. Blocks up to 37 meters in diameter have been observed in matrix and blocks inferred to be part of the olistostrome ranging up to $200 \mathrm{~m}$ in length [6]. Mafic volcanic rocks tend to form the largest blocks.

Multiple deformation events affected the rocks [37]. In particular, an earlier phase of extension produced tensional joints, some "soft-sediment faults," and some shear fractures, whereas a later episode of compression induced shortening that yielded folds and faults. These deformations affected the matrix fabric and the overall structure of the olistostrome. 
Table 2. Exotic block content of selected Franciscan mélanges.

\begin{tabular}{|c|c|c|c|c|c|c|c|c|c|c|c|c|c|c|c|}
\hline 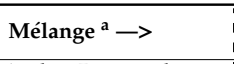 & $\begin{array}{c}\text { King Ridge } \\
\text { Road }^{\mathrm{c}}\end{array}$ & Laytonville & Hillside & $\begin{array}{c}\begin{array}{c}\text { Heaven's } \\
\text { Beach }\end{array} \\
\end{array}$ & $\begin{array}{l}\begin{array}{l}\text { Gerber } \\
\text { Ranch }\end{array} \\
\end{array}$ & Garzas & $\begin{array}{l}\text { Liberty } \\
\text { Gulch } \\
\end{array}$ & \begin{tabular}{|c} 
Crescent: \\
City
\end{tabular} & $\begin{array}{c}\text { Blue Rock } \\
\text { Springs }\end{array}$ & $\begin{array}{c}\text { Rodeo } \\
\text { Cove }\end{array}$ & $\begin{array}{c}\text { Hunters } \\
\text { Point }\end{array}$ & $\begin{array}{l}\text { Ingram } \\
\text { Canyon } \\
\end{array}$ & $\begin{array}{c}\text { Jenner } \\
\text { Headlands }\end{array}$ & $\begin{array}{c}\text { Ring } \\
\text { Mountain } \\
\end{array}$ & $\begin{array}{c}\text { Redwood } \\
\text { City }\end{array}$ \\
\hline $\begin{array}{l}\text { Author Proposed } \\
\text { Origin }{ }^{\mathrm{b}}\end{array}$ & $\mathrm{s}$ & $\mathrm{s}$ & $\mathrm{s}$ & $\mathrm{P}(\mathrm{S}, \mathrm{T})$ & $\mathrm{T}$ & $\mathrm{T}$ & $\mathrm{s}$ & $\mathrm{s}$ & $\mathrm{s}$ & $\mathrm{T}$ & $\mathrm{T}$ & $\mathrm{T}$ & $\mathrm{T}$ & $\mathrm{S}, \mathrm{T}$ & $\begin{array}{c}\text { D; } \\
\text { (T-herein) }\end{array}$ \\
\hline Matrix type $^{c}$ & Ss & MS & MS & MS & MS & MS; M & M; MS & $\mathrm{M}$ & $\mathrm{M}$ & $\mathrm{M}$ & $\mathrm{M}+\mathrm{Sp}$ & $M+S p$ & $\mathrm{Sp}$ & Sp & $\mathrm{Sp}$ \\
\hline \multicolumn{16}{|c|}{ Ocean Plate Stratigraphy Rocks (see rock types below) } \\
\hline $\begin{array}{l}\text { Serpentinized } \\
\text { peridotite, pyroxenite }\end{array}$ & & & $\sqrt{ }$ & $\sqrt{ }$ & & 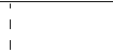 & & $\sqrt{ }$ & & & $\sqrt{ }$ & & $\sqrt{ }$ & $\sqrt{ }$ & $\sqrt{ }$ \\
\hline Serpentinite & $\sqrt{ }$ & & & $\sqrt{ }$ & & 1 & & & $\sqrt{ }$ & & $\sqrt{ }$ & $\sqrt{ }$ & $\sqrt{ }$ & $\sqrt{ }$ & $\sqrt{ }$ \\
\hline Basalt and metabasalt & $\sqrt{ }$ & $\sqrt{ }$ & $\sqrt{ }$ & $\sqrt{ }$ & $\sqrt{ }$ & $\sqrt{ }$ & $\sqrt{ }$ & $\sqrt{ }$ & $\sqrt{ }$ & $\sqrt{ }$ & $\sqrt{ }$ & $\sqrt{ }$ & $\sqrt{ }$ & $\sqrt{?}$ & $\sqrt{ }$ \\
\hline Chert and metachert & $\sqrt{ }$ & $\sqrt{ }$ & $\sqrt{ }$ & $\sqrt{ }$ & $\sqrt{ }$ & $\sqrt{ }$ & $\sqrt{ }$ & $\sqrt{ }$ & $\sqrt{ }$ & $\sqrt{ }$ & $\sqrt{ }$ & $\sqrt{ }$ & $\sqrt{ }$ & $\sqrt{?}$ & $\sqrt{ }$ \\
\hline $\begin{array}{l}\text { Sandstone and } \\
\text { metasandstone }\end{array}$ & $\sqrt{ } ?$ & $\sqrt{ }$ & $\sqrt{ }$ & $\sqrt{ }$ & $\sqrt{ }$ & $\sqrt{ }$ & $\sqrt{ }$ & $\sqrt{ }$ & $\sqrt{ }$ & $\sqrt{ }$ & $\sqrt{ }$ & $\sqrt{ }$ & $\sqrt{ }$ & $\sqrt{ } ?$ & $\sqrt{ }$ \\
\hline $\begin{array}{l}\text { Conglomerate and } \\
\text { metaconglomerate }\end{array}$ & & & $\sqrt{ }$ & $\sqrt{ }$ & $\sqrt{ }$ & $\sqrt{ }$ & & & $\sqrt{ }$ & 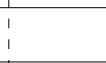 & $\begin{array}{l}\vdots \\
\vdots\end{array}$ & $\sqrt{ }$ & $\sqrt{ }$ & & ; \\
\hline \multicolumn{16}{|c|}{ Other Exotic Rocks } \\
\hline Glaucophane schist & $\sqrt{ }$ & $\sqrt{ }$ & & $\sqrt{ }$ & & $\sqrt{ }$ & $\sqrt{ }$ & & $\sqrt{ }$ & & $\sqrt{ }$ & $\sqrt{ }$ & $\sqrt{ }$ & $\sqrt{ }$ & $\sqrt{ }$ \\
\hline Eclogite & $\sqrt{ }$ & & 1 & & 1 & $\sqrt{ }$ & & 1 & & 1 & & $\sqrt{ }$ & $\sqrt{ }$ & $\sqrt{ }$ & 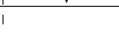 \\
\hline $\begin{array}{l}\text { Hornblende schist and } \\
\text { gneiss }\end{array}$ & $\checkmark$ & & & $\sqrt{ }$ & & $\checkmark$ & & & & & $\sqrt{ }$ & $\checkmark$ & $\checkmark$ & $\checkmark$ & $\sqrt{ }$ \\
\hline $\begin{array}{l}\text { Volcanic rocks other } \\
\text { than basalt }\end{array}$ & $\sqrt{ }$ & & & & 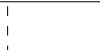 & 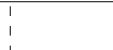 & & $\sqrt{ }$ & $\sqrt{ }$ & & & $\sqrt{ }$ & & $\sqrt{ }$ & \\
\hline Granitoid rocks & $\sqrt{ }$ & & & $\sqrt{ }$ & 1 & $\frac{1}{1}$ & $\frac{1}{1}$ & $\sqrt{ }$ & $\sqrt{ }$ & 1 & & & & & \\
\hline Other & $\sqrt{ }$ & $\sqrt{ }$ & & $\sqrt{ }$ & $\sqrt{ }$ & $\sqrt{ }$ & & $\sqrt{ }$ & $\sqrt{ }$ & & $\sqrt{ }$ & $\sqrt{ }$ & $\sqrt{ }$ & $\sqrt{ }$ & $\sqrt{ }$ \\
\hline a_Sources & [40] & {$[28,39,40]$} & \begin{tabular}{|c|}
{$[20,42-$} \\
$44]$ \\
\end{tabular} & {$[3,32]$} & $\begin{array}{c}2,45, \\
1 \quad 48] \\
\end{array}$ & $\begin{array}{l}{[2,11,43,} \\
146-49] \\
\end{array}$ & \begin{tabular}{l}
{$[32,42]$} \\
\hdashline
\end{tabular} & 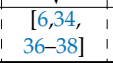 & {$[2,45]$} & $\begin{array}{c}\text { : } 23,50, \\
51] \\
\end{array}$ & {$[54]$} & \begin{tabular}{|c|} 
\\
$\quad[2,45$, \\
1 \\
\end{tabular} & {$[7,52,53]$} & {$[3,55,56]$} & [57] \\
\hline
\end{tabular}

a_-Sources; ${ }^{\mathrm{b}}-\mathrm{S}=$ sedimentary, $\mathrm{D}=$ diapiric, $\mathrm{T}=$ tectonic, $\mathrm{P}=$ polygenetic; ${ }^{\mathrm{c}}$-Arranged by matrix type: Sandstone (Ss), Mudrock + Sandstone (MS), Mudrock (M), Serpentinite (Sp). 
The evidence of a sedimentary origin for the Crescent City Olistostrome is compelling (Table 1), hence the name. Three of four defining features of sedimentary mélanges are exhibited, as are a total of 13 of 15 features characteristic of sedimentary mélanges. Nevertheless, later tectonism has given this mélange a tectonic overprint, resulting in some shearing and folding characteristic of tectonic mélanges (Table 1). As a result, 13 of 16 features characteristic of tectonic mélanges, including one of the definitive features of this type of mélange (scaly fabric with microbreccia), are present. Most fragmentation and mixing, however, are attributable to erosion and sedimentary processes, thus the mélange is fundamentally sedimentary in origin.

\subsubsection{The Laytonville Mélange}

The Laytonville Mélange, exposed in the central northern Coast Ranges (Figure 1, LY), occurs in mountainous terrain generally known as the "Central Belt" of the Franciscan Complex [5,28,39,59]. The unit was named for rocks in the vicinity of Laytonville, California [28], but small-scale mapping suggests that the unit may be laterally extensive [39].

Mapping of the Laytonville Mélange in the Laytonville region-and to the west, north, and south-was conducted by Gucwa, Kleist, and Jayko et al. [28,39,40]. The reconnaissance mapping of Jayko et al. [39] lumps all mélange rocks in the region together, apparently under the assumption that the Central Belt is predominantly a single large mélange unit (with admixed, smaller kilometer scale masses of other rock). Under such an assumption, in the geographic regions underlain by mélange, the mélange cannot be subdivided into multiple mélange (and non-mélange) units; yet, Gucwa $[28,60]$ did so. The presence of distinctive red (Laytonville) limestone and unusual Fe-rich rocks (ironstones) exclusively in this mélange makes this mélange unique relative to others in the Franciscan Complex [28,39,60-62].
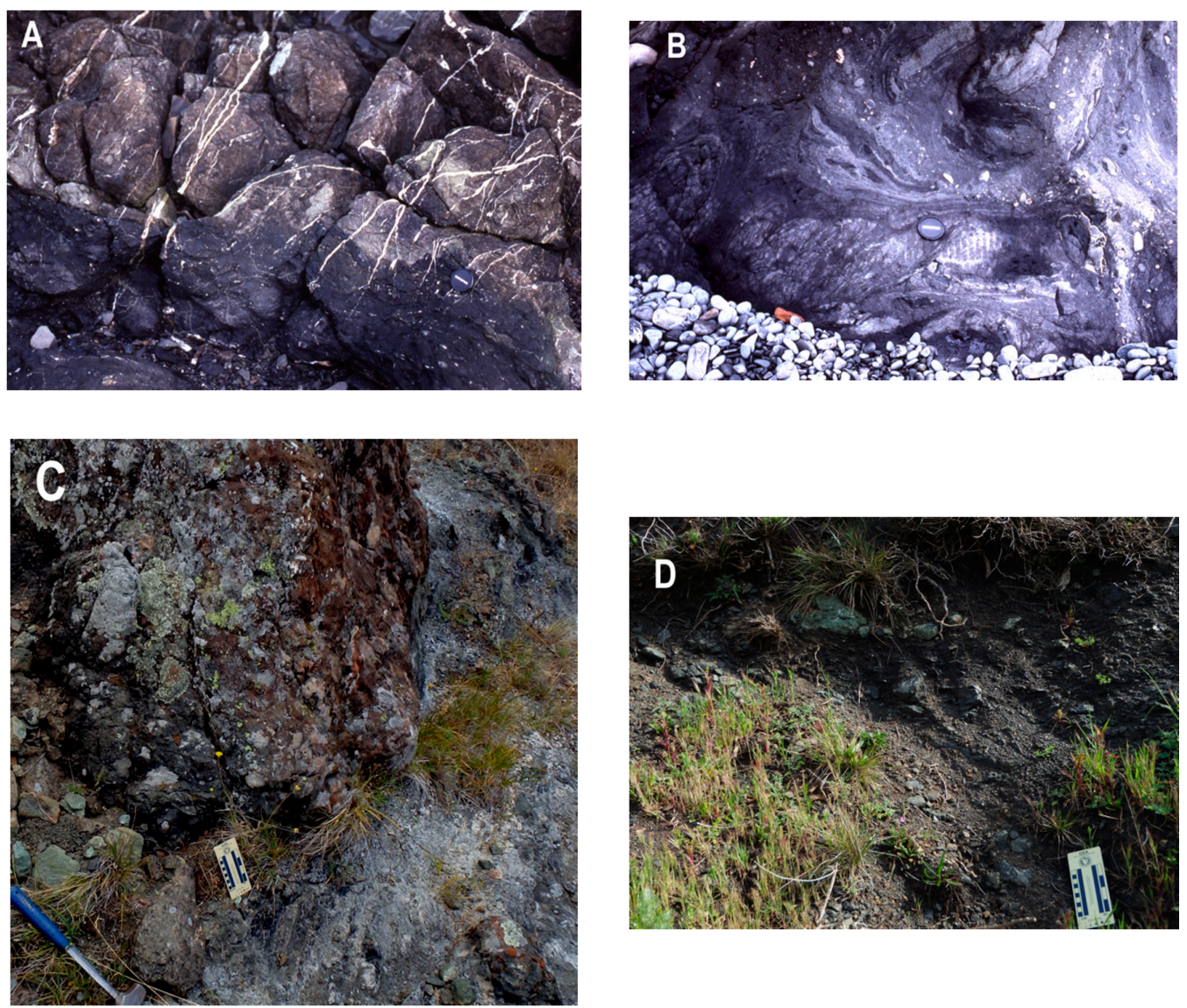

Figure 2. Cont. 

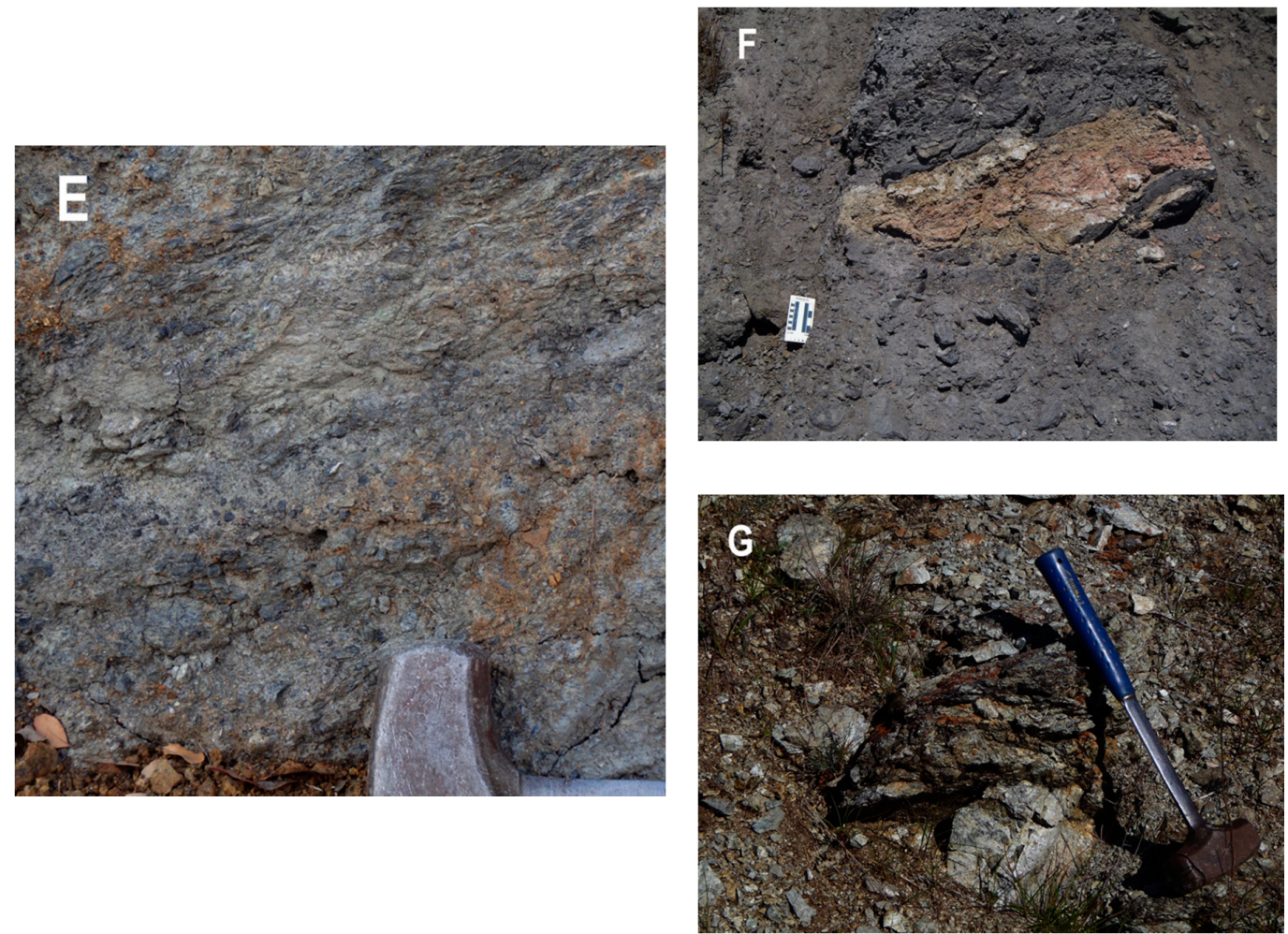

Figure 2. Photographs of outcrop features supporting mélange origin interpretations. A-C support sedimentary interpretations. (A) Overturned depositional contact of Crescent City Olistostrome (dark) on gravelly turbidite (medium gray), Pt. St. George, California (see [6]). Note that both turbiditic gravelly sandstone and muddy olistostrome are overprinted by approximately layer-parallel spaced cleavage and orthogonal veins. (B) Soft sediment folding, injection, and associated deformation with zones of pebbly, isotropic fabric. Crescent City Mélange, Pt. St. George, California. Circle in center is lens cap (approximately $5 \mathrm{~cm}$ diameter). (C) Metasandstone olistolith (upper left) in bedded mudrock matrix (see beds in lower center-below scale). Liberty Gulch Broken Formation, Member 1, Central Marin County, California [32]. D-G support tectonic history. (D) Metabasite ("greenstone") and metasandstone phacoids in scaly shale matrix, Rodeo Cove Mélange, below Conzelman Rd., east of Battery Rathbone. (E) Scaly mudrock and mudrock-metasandstone breccia, mélange matrix, Garzas Mélange, Mines Road, Section 13/24 boundary north of Western Mines Rd., California, near 37²4' N, $129^{\circ} 29^{\prime}$ W. (F) Scaly and breccia matrix enclosing chert block. Heavens Beach Mélange, northern Blind Beach, south of Goat Rock (see [3,32], Figure 6 of this report). (G) Scaly serpentinite matrix enclosing serpentinite block in serpentinite-matrix, Ring Mountain Mélange, southwest of the crest of Ring Mountain, Tiburon Peninsula, California (see [55]).

In map and cross sectional views, Gucwa $[28,60]$ suggests that the unit is tabular and about $8.5 \mathrm{~km}$ thick, which is astonishingly thick and unlikely for a single sedimentary mélange or even a sedimentary mélange complex. Folding in the unit may mean that the thickness is substantially less [40]. On maps, the contacts tend to appear somewhat irregular. To the east, Gucwa $[28,60]$ depicts the Laytonville mélange as depositionally overlying a Cretaceous sandstone unit along a predominantly sharp contact. To the west, Kleist [40] shows the mélange to overlie Cretaceous to Eocene "Coastal Belt" sandstones along a locally overturned contact that displays no evidence of shear or other deformational features. He discusses both olistostromal and fault juxtaposition of the two units here but reaches no conclusion. Jayko et al. [39] depict the eastern contact as a thrust fault and the western contact as a combination of a wide shear zone and various local, high-angle faults. The presence of possibly young Coastal Belt rocks below the Laytonville Mélange in less well-exposed relationships on the west may favor faulting 
along the western contact, but on the east, the Laytonville Mélange clearly appears to depositionally overlie a stratigraphic unit.

The matrix of the Laytonville mélange is clastic and is described by Kleist [40] as consisting of "greywacke-siltstone-mudstone". Jayko et al. [39] refer to the matrix of all mélanges in the region as "argillite". The muddy parts of the matrix, in particular, display scaly fabric.

Blocks in the mélange appear in angular to subrounded forms and range from a few centimeters to hundreds of meters in length $[28,39,40]$. No well-rounded blocks or clasts are reported in the mélange. The largest blocks are mafic volcanic rock, chert, and (meta)sandstone masses (OPS fragments) of 2-3 kilometers in length [28,40], and Kleist [40] suggests that the sandstones may be interbeds rather than clasts. OPS fragments of pillow basalt, diabase, and volcanic breccia are the most abundant of the OPS fragments, but various chert and OPS affiliated sandstone blocks are also present in the mélange. In addition, the Laytonville Mélange contains blocks of red limestone, conglomerate, gabbro, serpentinite, "greenschist," glaucophane schist, and rare quartz-stilpnomelane-riebeckite schist and gniess [28,40,42,61,62]. Clearly, both exotic and native blocks are present.

Detailed analyses of deformational features in the Laytonville Mélange have not been reported. Some folds and scaly fabric are the only structural elements reported to date [40].

The origin of fragmentation and mixing within the Laytonville Mélange appears to have been a combination of weathering, erosion, and transportation processes that took place, at least in part, as mass flows in a submarine environment. In particular, the presence of blocks of formerly subducted rocks now metamorphosed to blueschist facies assemblages, such as blocks of glaucophane schist, testify to uplift, erosion, transportation, and re-deposition of previously subducted and metamorphosed accretionary complex rocks. That such Franciscan metamorphic and OPS rocks (and those of similar complexes) have been recycled is well documented $[32,41,63,64]$. This evidence combined with the depositional contact of the Laytonville Mélange with underlying rocks and the total of 12 of 15 features compatible with a sedimentary origin (Table 1), including the presence of three of the four major indicators, supports a sedimentary origin for at least a part of this unit.

The large thickness $(8.5 \mathrm{~km})$ of the Laytonville Mélange reported by Gucwa [28], however, remains a problem. This is simply too thick for an origin as a single mass flow deposit. While the unit exhibits $80 \%$ of the features indicative of a sedimentary origin, it has 11 of $16(69 \%)$ of the features indicative of a tectonic origin. Could the Laytonville Mélange be an amalgamated unit consisting of multiple parts, including at least one sedimentary part and one tectonic part? Has folding given the mélange the appearance of excessive thickness by repeating section ([40], cf. Garzas Mélange, below)? Clearly, more detailed analyses are needed.

\subsubsection{The King Ridge Road Mélange}

Unlike the mudrock-matrix and mudrock + sandstone-matrix Crescent City and Laytonville mélanges, the King Ridge Road Mélange is a sandstone-matrix mélange [41]. The mélange is exposed in an area north of the lower reaches of the Russian River in Sonoma County, California (KR on Figure 1) and east of the well-known Jenner eclogite locality on the coast. The sandstone matrix of one exposure of mélange contains detrital zircons that suggest a maximum depositional age for the unit of $83 \mathrm{Ma}$ [41]. Sources of detrital zircons in the 85 to $55 \mathrm{Ma}$ age range-and especially in the range 75 and $55 \mathrm{Ma}$-have limited possible provenance areas in western North America, thus the actual depositional age could be younger [59,65-71].

The structural position of the main mass of King Ridge Road Mélange and the low K-feldspar content of the rocks $(\leq 5 \%)$ suggest an affiliation with rocks of the traditional "Central Belt" of the Franciscan Complex. On the other hand, since the depositional age is on the young end of the "Central Belt" age range and the old end of the Coastal Belt age range, the unit could be part of the traditional "Coastal Belt". The dated samples were collected from a body of rock assigned to the King Ridge Road Mélange by Erickson [41] but exposed to the west of the main body of King Ridge Road Mélange and separated from the latter. These rocks are atypical of the "Central Belt" and more typical of the "Coastal 
Belt" in being relatively high in K-feldspar (see K-feldspar data in Bailey et al. [72]). Thus, the age and the K-feldspar content combined with the structural position of the sampled body more likely indicate an affiliation with "Coastal Belt" rocks. The alternative is that the two masses of sandstone-matrix mélange are different units.

The King Ridge Road Mélange may be equivalent to the Wren Rock unit of Raymond and Bero [32] exposed near Jenner on the coast. That unit has a depositional contact with an underlying unit, has a sandstone matrix, and is dominated by OPS blocks-a contrast with the King Ridge Road Mélange, which has a more diverse clast content. The Wren Rock and the King Ridge Road units have similar structural positions, but it may be significant that the Wren Rock unit is not known to have the diversity of clast types present in the King Ridge Road Mélange, as reported by Erickson [41].

The clast population of the King Ridge Road Mélange is more diverse than many other mélanges described in the Franciscan Complex (Table 2) [41]. The blocks and the smaller fragments include some typical fragments of OPS and an array of other rocks types, including granitoid rocks and intermediate-silica volcanic rocks, plus glaucophane schist and re-metamorphosed eclogite. Block and clast sizes range from less than $2 \mathrm{~m}$ to about $1 \mathrm{~km}$ [41].

As with the Laytonville Mélange, the King Ridge Road Mélange contains clasts and blocks that have a pre-fragmentation and mixing history (e.g., blocks with foliation cut by the block margin). Considering the sandstone matrix of the mélange, they could represent uplifted, eroded, transported, and re-sedimented rocks formed via fragmentation and mixing that was a sedimentary process. Although the King Ridge Road Mélange is known to have only nine of the features typical of sedimentary mélanges, the sandstone matrix, the block-matrix contact described by Erickson [41], the diversity of clasts from non-oceanic sources, and the depositional contact between the potentially equivalent Wren Rock unit and underlying rocks all favor a sedimentary origin.

\subsubsection{Hillside Mélange}

The Hillside Mélange of El Cerrito was described in considerable detail by Wakabayashi [20,43,44]. In map view, the Hillside Mélange forms a rather narrow, linear outcrop belt [43], and cross sections show it to be tabular with a structural thickness of less than 50 to 200 meters [2,44]. The contact is reportedly a depositional one of mélange on prehnite-pumpellyite facies metawacke [44], although extensive overprinting by spaced cleavage renders that relationship obscure.

The mélange consists of OPS blocks in a sandy to muddy matrix $[3,44]$. The matrix has a fabric that ranges from anisotropic scaly to isotropic, the latter in little deformed domains where the textures are clastic conglomeratic to breccia textures. Near (but not at) the base, the rock is foliated above the contact [44]. Blocks and clasts consist of "greywacke," chert, metabasites, and rare peridotite. Maximum block size is $60 \mathrm{~m}$, and the blocks range from rounded to angular.

The upper contact zone of the mélange is a "black rock" fault zone interpreted by Wakabayashi and Rowe [44] to be a megathrust. The zone is $20-30 \mathrm{~m}$ thick with local areas of breccia, pseudotachylite, and ultramylonite.

The Hillside mélange exhibits 11 of the 15 features of sedimentary mélanges (73\%), including two of four major features. No fossils in the matrix or interlayered sedimentary units are known. The superimposed "megathrust" fault at the top of the unit and the zones of scaly fabric within indicate that the mélange had a significant structural history. It exhibits 13 of 16 features characteristic of tectonic mélanges $(81 \%)$, including two of the three major features.

\subsubsection{Other Sedimentary Mélanges}

The other sedimentary mélanges listed in Tables 1 and 2 include the mélange of Liberty Gulch [32] and the Blue Rock Spring Mélange [2,45]. The Blue Rock Spring Mélange has a diverse clast population such as the King Ridge Road Mélange but has a mudrock matrix (Table 2). The Mélange of Liberty Gulch also has a mudrock matrix, but the clast population is limited, consisting primarily of OPS rocks and rare glaucophane schist (Table 2). 
The Mélange of Liberty Gulch is mapped as part of a sedimentary sequence [32]. It forms the uppermost unit of a four-member broken formation and overlies a second member of the formation along a somewhat sheared contact interpreted to be a locally deformed depositional contact (Figure 3). Truncated foliations at block margins, blocks apparently resting within the matrix and deforming the underlying matrix slightly at the contacts (Figure 2C), and stratigraphic concordance with surrounding stratigraphic layers support the sedimentary histories of both the Blue Rock Spring and the Liberty Gulch mélanges. Each mélange has 10 or more features characteristic of sedimentary mélanges and two or three of the major indicators of a sedimentary history (Table 1).

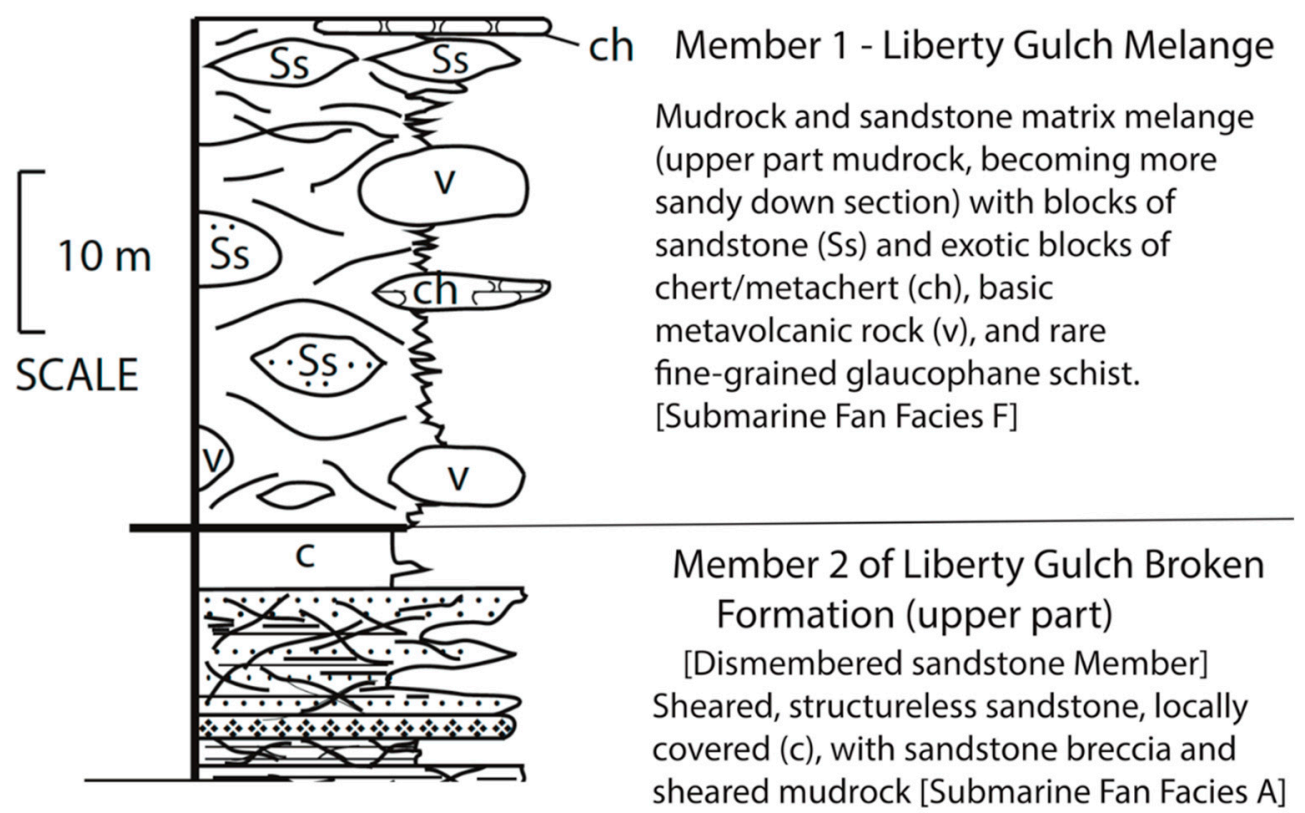

Figure 3. Section of Liberty Gulch Mélange (member) and underlying Dismembered Formation Member 2 of Liberty Gulch Broken Formation. Mélange (submarine fan facies F) conformably overlies Dismembered Sandstone Member 2, a sheared submarine fan facies A unit with local interbedded sheared mudrock (modified from [32]).

The Blue Rock Spring Mélange in the northeastern Diablo Range (BR, Figure 1) was mapped by Raymond [19,45] and Raymond and Maddock (unpublished, but see Wagner et al., [73]). It is a minimum of $300 \mathrm{~m}$ thick. The unit is tentatively considered to be a mass flow deposit complex. The matrix, which is dominantly mudrock, encloses clasts of metawacke with metamudrock, metaconglomerate, metachert, metabasalt, metadiabase, metagabbro, siliceous metavolcanic rock, glaucophane schist, marble, chlorite schist, and mica schist (Figure 4B,C). The largest indisputable blocks, the larger of which is about 400 meters long, are two metagabbro \pm metadiabase \pm metabasalt + metachert OPS fragments with minor inter-pillow, weakly recrystallized limestone (structurally dominated by relict bedding but with large carbonate ghost-crystals) (Figure 4B). Four large layers of submarine fan facies metawacke-including one 90 meters thick and 3.5 kilometers long and another more than 6 kilometers long-occur within the outcrop belt (Figure 4A) [45]. These masses of metawacke are (1) interbeds within mélange, (2) large slabs rafted downslope into the trench basin within a large submarine landslide, or (3) slabs of subducted submarine fan incorporated into a tectonic mélange underplated beneath the middle accretionary complex of the sequence shown in Figure 4. The data are inconclusive. The Blue Rock Springs Mélange has 10 of 15 features characteristic of sedimentary mélanges (67\%), including two of the four definitive features, but it also has 11 of 16 features of tectonic mélanges (69\%), including two of three definitive features (Table 1). In spite of having sheared contacts, the mélange is currently interpreted to be a mélange complex of sedimentary origin. 


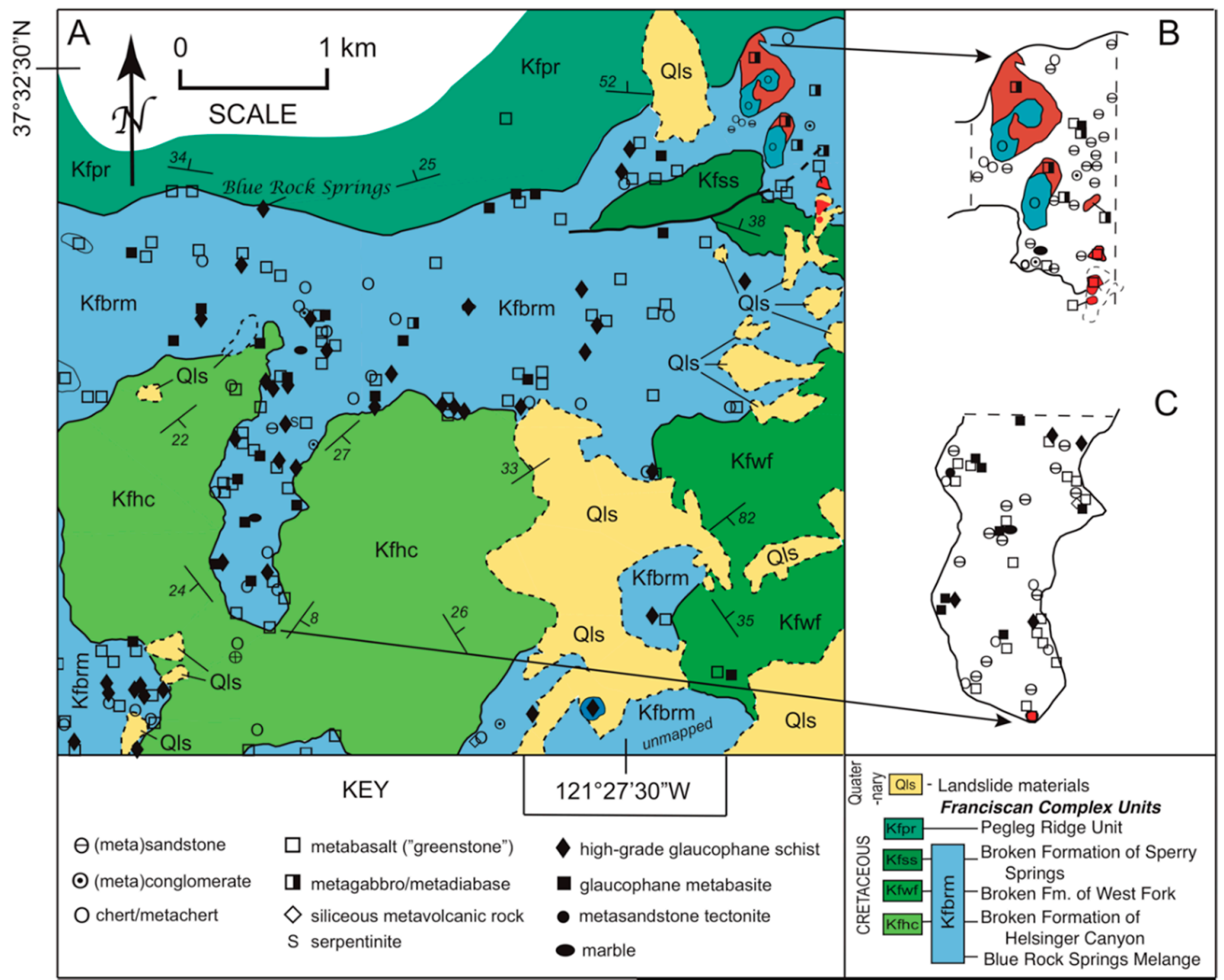

Figure 4. Maps of parts of the Blue Rock Spring Mélange. (A) General map of the Blue Rock Spring Mélange (Kfbrm) in the SW1/4 of the Lone Tree Creek 7.5' Quadrangle, California. Note metasandstone slabs associated with and largely surrounded by the Kfbrm (including Kfss, the metawacke of Sperry Springs; Kfwf, the Metawacke of West Fork; and Kfhc, the Metawacke of Helsinger Canyon (units from [2]). Qls is Quaternary landslide material. The structurally overlying unit is the Broken to Dismembered Formation of Pegleg Ridge (Kfpr)/Pegleg Ridge Mélange (nature of unit is unresolved). Exotic blocks are diverse but not evenly distributed in the Kfbrm. Details of block distribution showing more blocks than the general map are shown for two areas of the mélange (shown in $\mathbf{B}$ and $\mathbf{C}$ ). (B) Block map of area B, which contains some large masses of ocean plate stratigraphy (OPS), specifically metagabbro/metadiabase overlain by metachert (with local, red, interpillow weakly recrystallized metalimestone). Although the OPS blocks are the largest, native and exotic metasandstones are most abundant. The key shows other exotic block types. (C) Map of blocks in area C. See key for rock types. Metsandstones and metvolcanic metabasites are the most abundant, but high-grade blocks (mostly glaucophane schist) and lower-grade glaucophane metabasites and zeolite to greenschist facies metabasites ("greenstones") are relatively common. Note that non-oceanic rocks such as siliceous volcanic rocks are very minor components of the mélange. The maps show a representative sample of block types in the larger mélange, and it is likely that not every large block was discovered, but in general, only blocks larger than about 1 meter in diameter are mapped. An exception is that small masses of marble (any $>15 \mathrm{~cm}$ ) are included on the map.

\subsection{Tectonic Mélanges}

From the late 1960s to the 1980s, many-perhaps most-Franciscan mélanges were thought to be tectonic in origin [8-11,16,74-77]. Tectonic mélanges were also thought by some to be massive units representing the entirety of an accreting subduction complex at a particular point in time [78,79]. While early arguments for sedimentary origins existed [21,28,80,81], those arguments were not widely applied 
to Franciscan rocks until later. Current conversations at meetings and the published observations and comments of researchers such as Cowan [12], MacPherson et al. [82,83], and Wakabayashi [3,20,43] suggest that tectonic mélanges may be less common than previously thought and may be decidedly subordinate to sedimentary mélanges in the Franciscan Complex [43]. Wakabayashi $[3,33]$ even argues that many serpentinite-matrix mélanges had fragmentation and mixing histories that are primarily sedimentary in character.

Tectonic mélanges are still recognized in the Franciscan Complex and some are universally accepted as such. The one tectonic mélange described relatively recently by Wakabayashi [3] is the Rodeo Cove shear zone. He earlier also attributed fragmentation and mixing of the Hunters Point Mélange to tectonic processes [54]. The well-known Ring Mountain (serpentinite-matrix) Mélange is considered by Bero [55] to be tectonic in origin; however, as is discussed below and by Raymond [2], it has a disputed origin. A similar mélange at Jenner is considered to be of tectonic origin $[52,53]$.

\subsubsection{Rodeo Cove Mélange}

The Rodeo Cove Mélange is a fault zone mélange (i.e., a tectonic mélange) within the Marin Headlands Block of the Franciscan Complex located a short distance north of San Francisco (RC on Figure 1) $[19,23,50]$. This mélange was called the Rodeo Cove thrust zone by Meneghini and Moore [23], the Rodeo Cove mélange shear zone by Meneghini et al. [51], the Rodeo Cove shear zone by Wakabayashi [3], and a mélange comprising unit six of Marin Headlands by Raymond et al. $[46,47]$. In the most fully described section of the mélange at Rodeo Cove, the Rodeo Cove Mélange is atypical of tectonic mélanges, because the mélange is zoned, and parts of the described shear zone do not have typical block-in-matrix structure [23]. The mélange is traceable from west to east across the southern Marin Headlands and appears as a lenticular mass of variable thickness on maps and in sections (Figure 5). It lies structurally between two accretionary units (AUs) that contain broken formational OPS masses. The overlying unit, AU5 of Raymond et al. [46,47], is dominated by oceanic metabasalt but contains some (meta)chert. The underlying unit (AU7) is the Black Sands-Conzelman $\mathrm{AU}$, which contains parts of three OPS components-metabasalt, chert/metachert, and metasandstone (with meta-mudrock).

Inasmuch as the Rodeo Cove Mélange is a fault zone mélange, its boundaries with adjoining units are sheared, as is the matrix. The matrix varies from sheared metabasites to sheared mudrock, and it exhibits scaly foliation and cataclasite, but in the Rodeo Cove exposure, the matrix diminishes from the core towards the margins, especially the structurally lower margin (toward the north) [23]. Thus, the fault zone at Rodeo Cove is zoned in terms of deformation features. The southern edge of the shear zone, as defined by Meneghini and Moore [23], consists of structurally interlayered and juxtaposed broken formations of (meta)chert and metasandstone (not mélange). Towards the top of this zone of interlayering, stratal disruption increases and the shear-fractured-matrix derived predominantly from metabasalt and containing clasts of chert (one in excess of $10 \mathrm{~m}$ long) becomes the dominant rock of the mélange. The mélange displays P-R and S-C structures, notably in the core zone [23].

East of the excellent exposures studied by Meneghini and Moore [23], the Rodeo Cove Mélange is hidden beneath a lagoon and colluvium. Both Meneghini and Moore [23] and Raymond et al. [46,47] show the mélange extending east from beneath the colluvium and the lagoon, but Raymond et al. interpret the mélange to be unit six, whereas Meneghini and Moore interpret the mélange to be a unit two layers structurally lower (i.e., unit eight of Raymond et al. [46,47]). Here, I adopt the interpretation of Raymond et al. [46,47]. 


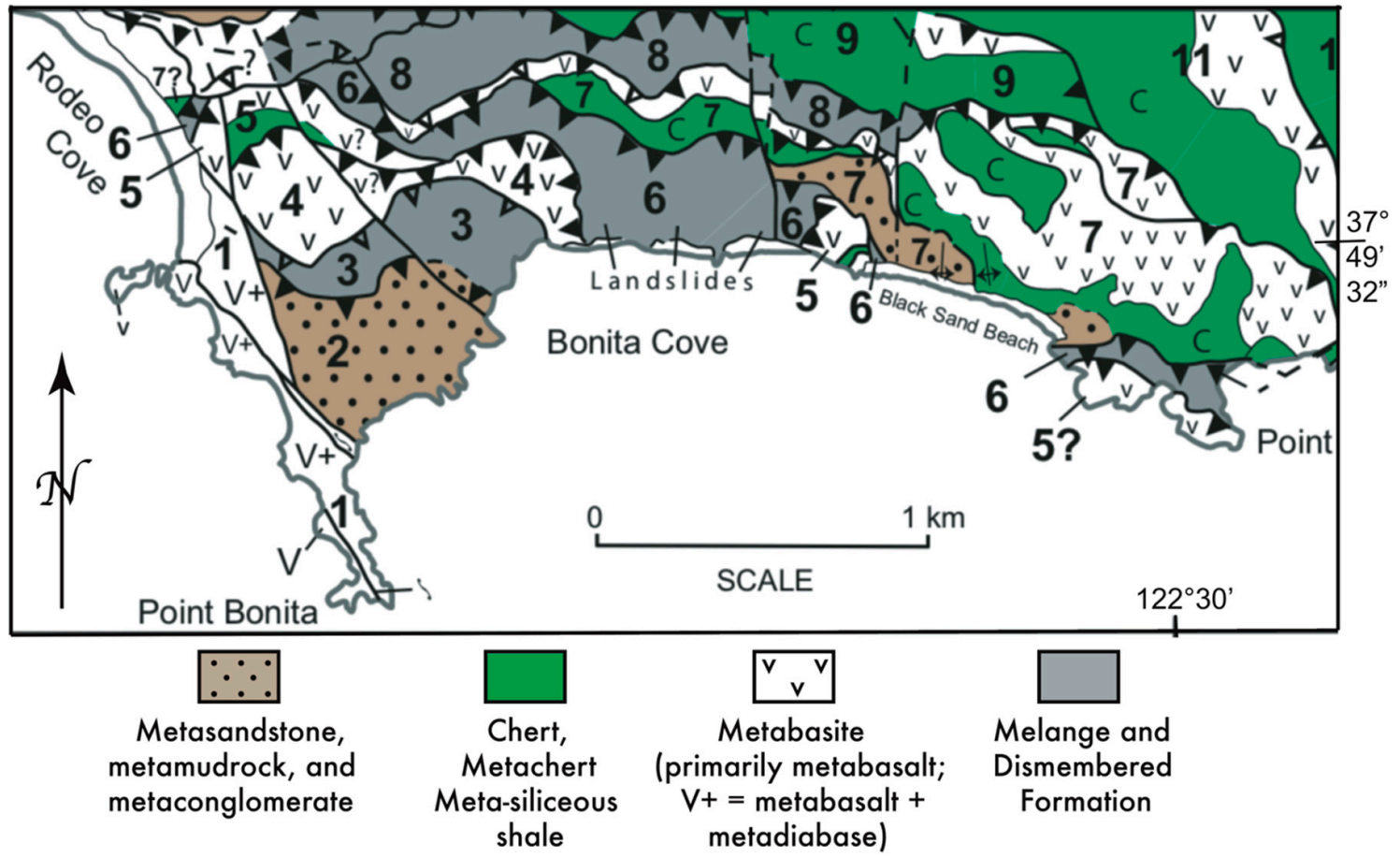

Figure 5. Geologic map of the southwestern, OPS-dominated, Marin Headlands block of the Franciscan Complex (after $[46,47]$ and based on $[23,50,51,84]$ and mapping by the author). Unit six is the Rodeo Cove Mélange.

The zone of mélange east of the lagoon is thicker and has a wider map dimension than exposures at Rodeo Cove (Figure 5). Here, the amount of matrix appears to increase, and "black rock" (pseudotachylite?) zones occur within this matrix. Large to small masses of metasandstone and metachert are exposed on steep slopes in the lower middle section of the mélange, and these are separated from one another by zones of scaly matrix containing small phacoids of metabasite, metasandstone, and metachert (Figure 2D). All of the clasts in the mélange appear to be OPS fragments and hence are metabasites, (meta)chert, or metasandstone \pm metamudrock. To date, the largest blocks known are several tens of meters long, but detailed mapping of the entire mélange has not been completed.

The tectonic origin of the Rodeo Cove Mélange is not in dispute. The mélange has 14 of the 16 features characteristic of tectonic mélanges and exhibits all three of those that are definitive (Table 1). Its structural position, character, and lack of any of the definitive features of diapiric or sedimentary mélanges strongly support a tectonic origin.

\subsubsection{The Ingram Canyon Mélange}

In contrast to the Rodeo Cove Mélange, the Ingram Canyon Mélange contains a diverse array of clast types. The unit (formerly called the Rocky Point Mélange [48]) forms an accretionary unit in the northeastern Diablo Range and lies at the structural top of the Franciscan tectonostratigraphy [45-47]. The Ingram Canyon unit may be correlative with the Garzas Mélange described to the south ([11,47-49,85,86], and see below), but the latter has been studied in less detail than the Ingram Canyon Mélange. Details of the nature and the structural relationships of the Garzas Mélange are not well enough known for a definitive correlation between the two units.

The Ingram Canyon Mélange forms a lenticular unit in map view and is tabular to wedge-shaped in cross section $[2,45-47,85]$. All contacts are faulted (sheared), but most faults on the north, the northeast, and the east are late Cenozoic strike-slip faults $[2,85,86]$. The fault at the structural base of the unit likely had a diachronous history. Following early thrusting beneath the overlying Coast Range 
Ophiolite (CRO) and later underthrusting by the Gerber Ranch Mélange, subsequent normal-slip movement likely occurred as the core of the Diablo Range rose during the late Cenozoic orogenic episode [87]. The block-in-matrix fabric is anisotropic and exhibits S-C fabrics and possible P-R fabrics (cf. S-C fabrics in the Garzas Mélange to the south [88]). Boudinage of clasts is common, and phacoids resulting from plastic extension are characteristic [48]. Folds occur in many blocks, but no regular mesoscopic folding is known within the mélange matrix. Scaly fabric pervades the matrix. Veins and striated phacoids and mélange "scales" bounded by anastomosing shears are common.

Both native and exotic blocks occur in the mélange and locally can be observed within the matrix, which varies from a serpentinite-mudrock mix in the north to a mudrock matrix in the south (see the map of block distribution for the mélange in $[47,48])$. In general, the scaly fabric of the matrix wraps around blocks, as is typical in tectonic mélanges. Blocks in the mélange range from serpentinite to sandstone and include conglomerate, garnet-glaucophane schist, chlorite-glaucophane metabasites (metagabbro and metabasalt), OPS fragments (including chlorite metabasites, chert and metachert, and metasandstone), plus uncommon siliceous metavolcanic rocks and chlorite schist [46-48]. In addition, rare actinolite schist, retrograde metamorphosed and veined eclogite, and aragonite marble occur locally.

The Ingram Canyon Mélange has been studied only by Raymond [45,47] and Raymond and Maddock [46,47]. It exhibits all of the features of tectonic mélanges, including the three diagnostic features. It has been argued, however, by Wakabayashi [3] (following MacPherson et al.) [82] that conglomerates and breccias with clasts of upper plate rocks, such as siliceous volcanic and plutonic (arc) rocks, suggest a sedimentary origin for a mélange. The conglomerates and the breccias are considered to represent remnants of the original sedimentary protoliths of the mélange, whereas the siliceous volcanic and the plutonic rocks, it is argued [3,82], must be clasts eroded via surficial processes from hanging wall terranes. While early-formed conglomerates, breccias, and diamictites may be overprinted by deformation and fragmented to form mélanges, as is clearly indicated by observational data $[3,32,63]$, the existence of arc-type rocks is not absolute evidence that all such rocks found in a mélange require sedimentary processes for the formation of the mélange. One alternative, a variant of the protolith argument, is that conglomerate and breccia fragments in mélanges may just be individual components of the trench sedimentary sequence that later becomes a tectonic mélange beneath the mid- to inner accretionary complex. Both versions of the protolith argument are especially tenable if the arc rocks occur as relatively small, well rounded clasts.

A second alternative to the argument that arc-like plutonic and volcanic rocks must represent upper plate rocks surficially eroded from an upper plate source and deposited in the trench to become parts of the protolith of a sedimentary mélange is a tectonic alternative. Angular or tectonically rounded clasts and large blocks of arc-like plutonic and volcanic rocks may represent components of the igneous forearc, off-scraped during subduction erosion and subsequently mixed with other rocks to form tectonic mélanges [19,89-94]. It seems unlikely, however, that more siliceous varieties or arc rock, which occur in mélanges such as the Ingram Canyon Mélange, could be produced by subduction erosion in an abscherungzone setting [19] during initiation of subduction. Such a process would contribute clasts to a tectonic mélange that most likely would be basic to ultrabasic lower arc rocks. For upper arc (more fractionated) rocks to be tectonically eroded at the subduction interface, the arc would need to be extended and thinned, exposing abbreviated sections of arc rocks, including upper arc rocks, to tectonic erosion. Such thinned sections of suprasubduction zone arc rocks are present above the fault separating the Ingram Canyon Mélange from the overlying Coast Range Ophiolite (CRO) forearc section $[45,47,85]$. Thin and incomplete, 200 to $350 \mathrm{~m}$ thick sections of the CRO forearc that include the siliceous Lotta Creek Tuff structurally overlie—above a sub-ophiolite fault—-the Ingram Canyon Mélange.

A similar configuration exists southwest of King Ridge Road near Occidental, California, where siliceous volcanic rocks in a highly thinned incomplete CRO section are juxtaposed with serpentinite-matrix and mudrock/sandstone-matrix mélange, the latter assigned to the "Central 
Belt" [95]. The presence of thinned forearc arc sections with siliceous components structurally overlying mélange that contains arc-like rocks provides a setting in which subduction erosion of ophiolite could yield arc rock-bearing mélange. The geometry is not conclusive evidence but is supportive of an alternative mode of mélange origin that should be considered.

The Ingram Canyon Mélange contains only seven features of sedimentary mélanges and none of those most definitive of that origin. In contrast, it contains 15 of the 16 features of tectonic mélanges, including three of the most indicative features. Thus, in spite of the presence of siliceous volcanic blocks in the mélange, the strong evidence of deformation suggests that this mélange formed via tectonic fragmentation and mixing.

\subsubsection{The Jenner Headlands Mélange}

At Jenner, there are two mélanges exposed in the sea cliffs/near-shore area and on surrounding hillsides (Figure 1, labels HB and JH; Figure 6) [7,32,53,96,97]. The cliffs expose the polygenetic Heaven's Beach Mélange [32], whereas areas on the hills near the ridge crest to the east of the cliffs (and north of the Russian River) have exposures of a serpentinite-matrix mélange [7,53], here called the Jenner Headlands Mélange. The Jenner Headlands Mélange is structurally overlain by serpentinized peridotite and locally overlies, above a thrust fault boundary, either an unnamed jadeitized, foliated metawacke unit (on the north in Figure 6) or the Wren Rock unit (an olistolithic broken formation or sandstone-matrix mélange) $[7,32,53]$.

In map view, the serpentinite-matrix Jenner Headlands Mélange forms several irregular to linear masses scattered across the terrain north of Jenner, California. It is a thin tabular to irregular unit in cross section [2]. The contacts are not well exposed but in all cases appear to be sheared, as are the exposed contacts between matrix and blocks.

The serpentinite matrix of the Jenner Headlands Mélange exhibits a scaly fabric that contains a variety of exotic blocks and clasts [53]. The matrix is anisotropic in structure with anastomosing shear planes, and it wraps around clasts and blocks (Figure 7A). The clasts and blocks range up to several tens of meters in long dimension and are rounded to lensoidal in shape [53]. Block rock types include typical metamorphosed OPS rocks [metabasites (metabasalt and metagabbro), metachert, and metasandstone] and conglomerate plus hornblende and glaucophane schist with chlorite-actinolite rims and veins, chlorite and serpentinite schists, and rare eclogite. Essentially, all of the blocks are exotic.

The fault-bounded Jenner Headlands Mélange is decidedly tectonic in origin, exhibiting 14 of the 16 features of tectonic mélanges, including two of the three definitive features. With the possible exception of some rounded blocks, the mélange has none of the definitive features of diapiric or sedimentary mélanges and only modest numbers of features that occur in two or more mélange types.

Of note here is that the tectonostratigraphy present at Jenner Headlands is repeated elsewhere in the region. The uppermost trectonostratigraphy of the Franciscan Complex includes a mélange-typically a serpentinite-matrix mélange that structurally underlies a blocky serpentinized to massive peridotite unit usually assigned to the Coast Range Ophiolite. Beneath the mélange, the common units that occur successively downward are a foliated blueschist facies unit and a structurally underlying prehnite-pumpellyite facies, metasandstone-metamudrock unit. This sequence occurs at Jenner, at Freestone to the southeast, and on the Tiburon Peninsula near San Francisco (RM on Figure 1) [2,7,32]. Partial or similar sequences with the same order occur near Occidental (southeast of Jenner) and at El Cerrito (HM on Figure 1) $[2,44,53,95,98]$. In central Marin County, blocky serpentinized peridotite is underlain by a sheared serpentinite unit that is arguably a serpentinite-matrix mélange, and that unit is underlain by an olistostrome-bearing, prehnite-pumpellyite facies, metasandstone-metamudrock unit [32]. A blueschist facies unit has not been recognized in central Marin County. Repetition of a tectonostratigraphy across the northern San Francisco Bay region argues for a similar tectonic accretion history for the region and a similar history for the serpentinite-matrix mélanges. 


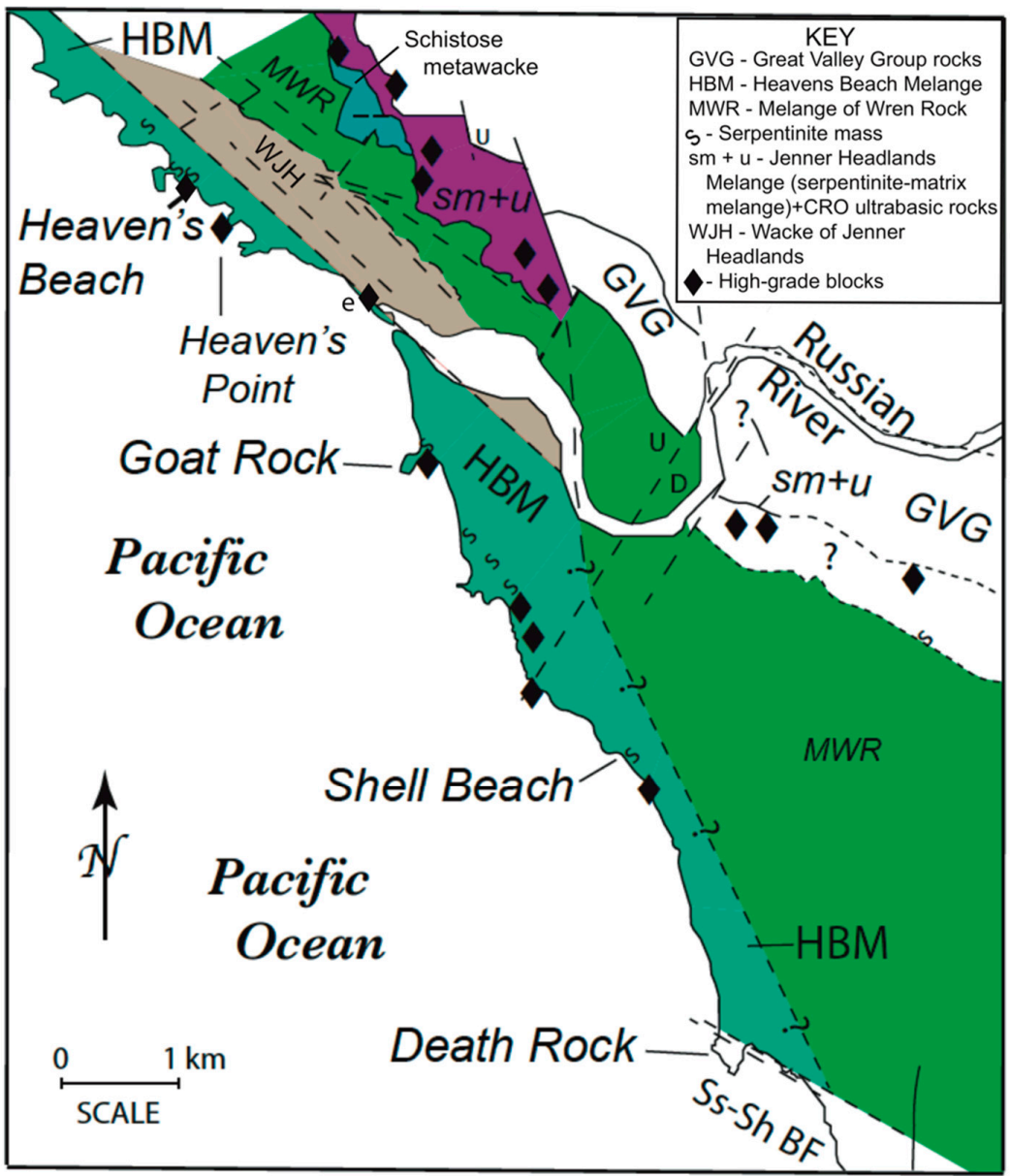

Figure 6. Simplified reconnaissance geologic map of part of the Sonoma County coast, California, showing the location of the eclogite-bearing Jenner Headlands Mélange and overlying rocks of the Coast Range Ophiolite (CRO), labeled together as $\mathrm{sm}+\mathrm{u}$, and the general extent of the Heaven's Beach Mélange (see [3,7,32,52,53,99-101]). Part of the northern area was mapped in detail by Bero [7] and Raymond and Bero [32]. The area between Goat Rock and Shell Beach was mapped in reconnaissance by Wakabayashi [3] and the author (unpublished). Preliminary reconnaissance south of Shell Beach was done by the author. The eastern contact, a high-angle fault, is largely concealed beneath Quaternary marine terraces, landslide materials, and colluvium. The western contact is largely concealed beneath the Pacific Ocean. The well known Jenner eclogite locality, containing eclogites moved by landsliding from the Jenner Headlands Mélange to the road and beach downslope, is marked with a high-grade block symbol and the letter " $\mathrm{e}$ " (see $[52,53])$.

\subsubsection{Other Tectonic Mélanges}

Several other mélanges that have been designated as tectonic in origin are listed in Table 1. These include the Garzas Mélange, the Gerber Ranch Mélange, and the Hunters Point Mélange. The Garzas Mélange (GZ on Figure 1) is a shale-matrix mélange that is exposed over a wide area in the northeastern Diablo Range [11,45,49,102]. Preliminary regional structural analysis suggests that the mélange may not be as thick as it seems, inasmuch as the folding patterns shown by Raymond $[2,45,87]$ for the region result in repetition of mélange sections. The mudrock-matrix Garzas Mélange has a relatively diverse range of native and exotic block types, including blocks of so-called "high-grade" glaucophane schist $[11,49]$. Scaly and brecciated textures are common in the matrix (Figure 2E) and define an anisotropic fabric that is also reflected by S-C fabrics in metawackes [88].

The Gerber Ranch Mélange structurally underlies the Ingram Canyon Mélange [45-49]. It is distinct from the latter in its lack of both serpentinite bodies and blocks of "high-grade" glaucophane 
schist and related rock types. Numerous blocks of lower grade glaucophanized metabasites occur in the Gerber Ranch Mélange, and these are accompanied by other OPS fragments of metachert and metasandstone, all metamorphosed under jadeite blueschist facies conditions $[45,48,85]$. Other clasts and blocks include conglomerate plus rare marble and actinolite schist. The blocks tend to be elliptical, reflecting elongation parallel to the strike of the scaly mudrock fabric of the mélange.

The Hunters Point Mélange on the San Francisco Peninsula (HP, Figure 1) is a complex body that is not well understood, in part because of the limited outcrops available within a city environment. The unit was mapped by Schlocker [103] and Bonilla [104] and designated by Schlocker as the Fort Point-Potrero Hill-Hunters Point Shear Zone, shortened to Hunters Point Shear Zone by Wakabayashi [3,54,105]. Wakabayashi [54] describes a layered/zoned map pattern with a large serpentinite mass between regional layers of shale-matrix mélange. In detail, however, the zones of sheared (scaly) matrix in the mélange vary spatially from serpentinite to serpentinite+ mudrock to mudrock [103]. The matrix contains rounded to elongate blocks and clasts of various rock types, including sandstone, chert, metabasites (including gabbro), serpentinite, and metamorphic rocks (e.g., hornblende schist) $[54,103,105]$. The largest block is approximately $1 \mathrm{~km}$ in length, but most are substantially smaller. The Mélange of Hunters Point exhibits two of the definitive features of tectonic mélanges and 11 features of such mélanges overall.

\subsection{Diapiric Mélanges}

Diapiric mélanges are rare in the Franciscan Complex. Two descriptions of diapiric mélanges in the Sur-Obispo Complex (formerly included in the Franciscan Complex-see [2]) are presented by Becker and Cloos [106] and Ogawa et al. [107]. The only Franciscan mélange assigned a diapric history in the region covered by this review is the Serpentinite Mélange of Redwood City [57]. As indicted by the name, the mélange is a serpentinite-matrix mélange exposed on the peninsula south of San Francisco (RCS on Figure 1).

The Serpentinite Mélange of Redwood City has discordant, sheared contacts and native and exotic blocks [57]. Blocks range up to a few meters in maximum dimension and most are serpentinite, at least some of which are massive antigorite. Rare glaucophane schist with remnant omphacite occurs locally. The mélange presents an elongated, irregular map pattern, a sheet-like shape in section, P-R structures, anisotropic and local scaly fabric, and common veins. Of critical importance in understanding the mélange history is that it displays sheared contacts with an Eocene sandstone unit that unconformably overlies other Franciscan units [108]. This indicates that diapirism is of post-accretionary complex age, suggesting late Cenozoic remobilization of mélange materials formed earlier [109].

The mélange contains only three characteristics of diapiric mélanges and displays neither of the two definitive features of such mélanges. In contrast, it displays 12 of 16 features that occur in tectonic mélanges and all three of the definitive features of tectonic mélanges (Table 1). As such, the age of fragmentation and mixing is open to question and may be pre-diapirism. I here consider the mélange to be polygenetic as currently exposed but ultimately of tectonic — not diapiric —origin. All things considered, this mélange would better fit below within Section 3.4, which covers polygenetic mélanges and mélanges of disputed origin.

\subsection{Mélanges of Polygenetic and Debated Origin}

\subsubsection{The Heavens Beach Mélange}

The polygenetic Heavens Beach Mélange crops out near Jenner, California, north of San Francisco (Figure 1, HB; Figure 6) and was named for a beach of that name [32]. The almost continuous mélange exposures have an along-strike length of more than 10 kilometers, encompassing the type section north of Jenner and rocks to the south at Goat Rock to Shell Beach and beyond $[3,32,53,99]$. The mélange unit as a whole is irregularly linear in map view. The western contact of the mélange is concealed beneath waters of the Pacific Ocean. In rare exposures, the eastern boundary appears to be a high-angle fault 
and is thus a sheared contact. Inasmuch as the western contact is concealed, the cross-sectional nature of the mélange is unknown.

Internally, the mélange has a metasandstone-metamudrock matrix that locally has scaly fabric with anastomosing cleavage [53] and breccia zones (Figure 2F). Hence, the matrix is in part anisotropic. Within this matrix are large and small blocks of both native and exotic blocks. The native blocks are low-grade metasandstone of mid-fan character. Exotic blocks range from prehnite-pumpellyite facies metasandstones (dominantly sandy Fan Facies A, B, C, E) and dominantly metashale (Fan Facies D) to largely reconstituted, foliated, high-pressure metamorphic rocks (blueschist facies metasandstone tectonite, glaucophane schist, and hornblende schist and gneiss) [3,32]. Notable blocks are several serpentinite bodies (Figure 6), at least two of which include masses of serpentinite-matrix mélange. In addition, blocks include a mass of distinctive red chert-bearing conglomerate and a muddy sand-matrix olistostrome with stratigraphically overlying (but structurally underlying) conglomerate, both containing clasts of glaucophane schist. Both the olistostromal mélange of the tectonic block and the tectonic successor mélange contain blocks of mafic metabasite, metachert, and metasandstone, but the olistostromal unit and the conglomerate within the tectonic block also contain clasts of plutonic igneous rocks. Blocks and clasts range in size from a few centimeters to blocks of about $600 \mathrm{~m}$ in length $[3,32]$. Some of the smaller blocks likely were derived by fragmentation and intermixing of blocks of the olistostrome into the matrix of the successor tectonic mélange. Blocks are angular and blocky to subrounded to lenticular in shape, with the latter displaying local deformation "tails." Some blocks display folds_-primarily metachert and "high-grade" glaucophane schist/amphibolite blocks-but the matrix displays no obvious regional folding.

The olistostromal block in the Heavens Beach Mélange reveals sedimentary fragmentation, mixing, and deposition of sediment containing reworked Franciscan rocks (metabasites, metachert, metasandstone, glaucophane schist). The Heavens Beach Mélange in its present state, however, developed the dominant character of large to small blocks in a matrix of sheared sandstone-mudrock after deposition of the sandstone-, conglomerate-, and olistostromal diamictite in units that gave rise to blocks now present in the mélange. Thus, the mélange in part had a sedimentary precursor mélange that provided some material to the mélange. The now dominant block-in-matrix character is of tectonic origin. The mélange has 13 of the features characteristic of tectonic mélanges and two of the three definitive features (Table 1).

\subsubsection{The Ring Mountain Mélange}

The Ring Mountain Mélange is the most studied mélange of the Northern Coast Range-Diablo Range Franciscan Complex (Figure 1, RM, between RC and HM). Numerous studies of various aspects of the exotic blocks in the serpentinite-matrix mélange [52,55,56,105,110-114], limited study of the serpentinite matrix [3,115], and large-scale (detailed) mapping $[3,55,56,111]$ have both clarified many details of the mélange and led to conflicting interpretations (contrast [55] and [3]).

In map view, the Ring Mountain Mélange appears as an irregular, slightly elliptical, elongated ring-like body overlapped by irregular elliptical to ring-like masses of serpentinized peridotite capping parts of Ring Mountain [55,56]. In the cross section, the body is a thin, folded sheet $[55,56]$. The contacts are sheared. Internally, the serpentinite matrix displays anisotropic, scaly fabric with anastamosing shears that bound unsheared to less sheared phacoids of serpentinite and wrap around larger exotic blocks (Figure 2G). Apparent P-R structures contribute to the sheared character of the matrix. Macroscopic asymmetrical folds in the mélange are later-formed features that affect both overlying serpentinized harzburgite and underlying mélange. Mesoscopic folds also characterize many of the exotic blocks (Figure 7B) and the matrix (Figure 7C).

The blocks in the mélange are relatively abundant and both exotic and native in character $[3,43,55]$. Abundant native serpentinite blocks of a range of sizes are the most common. Exotic blocks and clasts ranging from a few millimeters to $140+\mathrm{m}$ in long dimension occur as a variety of rock types. These include both higher and lower grade blocks. The "high grade" blocks are garnet-hornblende 
gneisses and schists, eclogites, and glaucophane schists. The lower grade blocks include talc-chlorite \pm actinolite schists (that likely represent rims from or retrograde masses of higher grade blocks) and relatively rare folded schistose serpentinite tectonite (Figure 7B), dense knobby serpentinite tectonite, and siliceous volcanic rock. Some chert/metachert and foliated metasandstone masses in structurally ambiguous positions may be exotic blocks as well.

The features and the inferred origin of the mélange and its matrix are debated. Bero [55] essentially argues that the matrix is a tectonite formed at the base of the overlying harzburgite during thrusting over the underlying Franciscan rocks. Essentially, the structural position, the pervasive scaly fabric, the common serpentinite rims on clasts, the presence of boudins that could not survive sedimentary transport, and the regional distribution of similar rocks in tectonostratigraphic-like settings favor a tectonic interpretation.

A sedimentary origin is favored by Wakabayashi [3,33], who called the mélange the Tiburon Mélange. Three primary lines of evidence are offered in support of that view-(1) textural/structural evidence of rounding of grains and blocks, (2) breccia structure, and (3) photomicrographic evidence of various non-serpentinite, sand-size grains in the matrix. Rounded shapes of serpentinite blocks and clasts, as well as other clasts in the mélange, are a central issue. With regard to rounding, Bero [55] and Raymond and Bero [32] offer the alternative processes of weathering and tectonic erosion for the production of rounded serpentinite blocks that appear both on slopes and within the matrix (Figure 8A). Tectonic rounding has affected other Franciscan rocks [30] and reasonably may have affected the serpentinites. O'Hanley [31] describes and illustrates weathering "kernals" with rounded edges in serpentinites that result in rounded clasts. The Ring Mountain Mélange definitely has many rounded clasts of serpentinite and other rocks. A rounded block of glaucophane schist in the serpentinite matrix at Ring Mountain, for example, is reportedly enclosed in "serpentinite pebbly sandstone" [43] (Figure 8B). My examination revealed one area of serpentinite breccia (br) in the outcrop, a strongly to weakly foliated, scaly to blocky serpentinite matrix (sp) that wraps around small and large blocks and clasts, and a strongly and concentrically-foliated glaucophane schist block (gs), the internal foliation of which is paralleled at its margin by some foliations in adjoining serpentinite (Figure 8B). Overall, the fabric that appears sedimentary to Wakabayashi [43] appears tectonic to me.

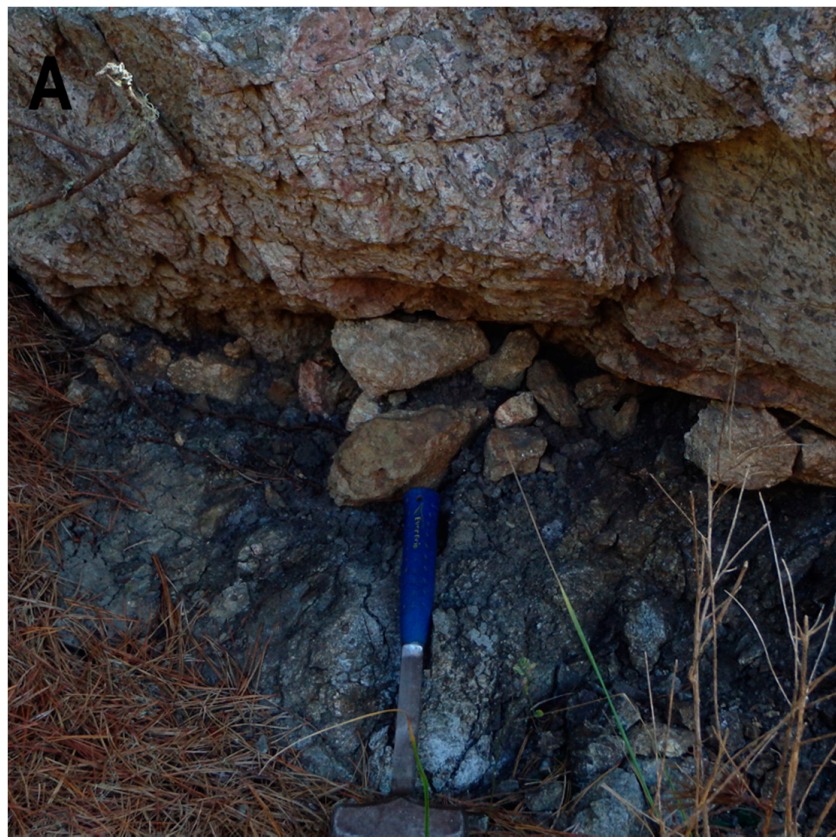

Figure 7. Cont. 

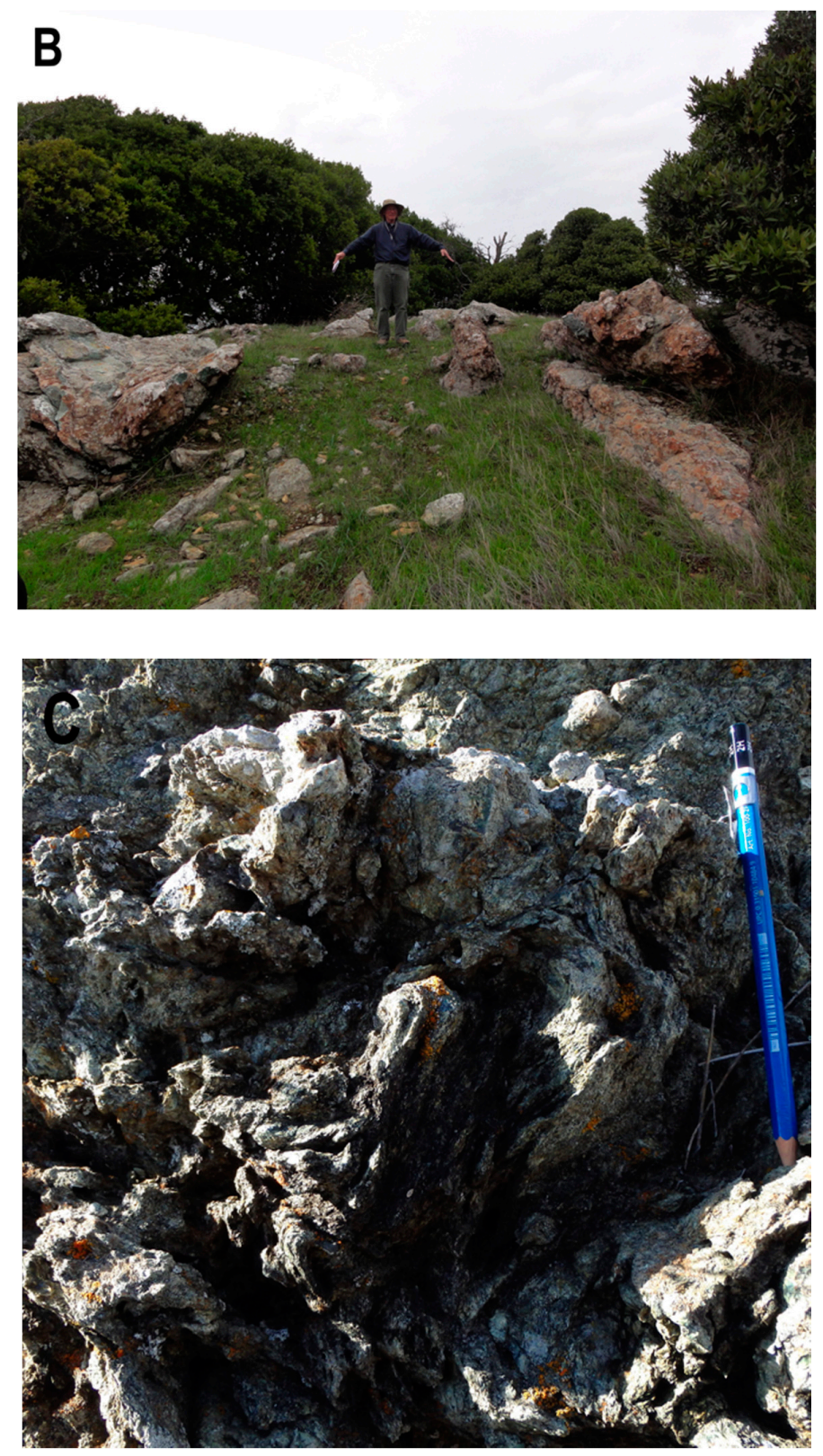

Figure 7. Some structures in serpentinite-matrix mélanges. (A) Boudin and foliation. The foliation in the serpentinite matrix (dark) bends to wrap around a large chert block (light) in the Jenner Headlands Mélange. Note the bend in foliation towards parallelism with the contact at the lower right behind grass and at the left center, where the matrix encloses a small boudinaged layer of chert (modified from [54]); $40 \mathrm{~cm}$ hammer provides scale. (B) Folds in exotic serpentinite tectonite (schist) block in the Ring Mountain Mélange. Author's arms point in directions of dip, away from the antiformal axis. Note the smaller synformal fold axial region to the left. (C) Folds in the serpentinite matrix of Ring Mountain Mélange. Pencil, for scale, is about $6 \mathrm{~cm}$ long.

In the absence of other compelling evidence of sedimentary processes acting on the mélange matrix, tectonic rounding-and in some cases, weathering - seem the better explanation for the rounding. The same seems reasonable for other evidence. Local breccias consisting of serpentinite fragments in a serpentinite matrix may be attributed to tectonism. Sand-size grains in the serpentinite matrix, the grains reported by Wakabayashi [3,33], include hornblende, glaucophane, plagioclase, garnet, and rutile-all components of the blocks included in the mélange. More compelling would be the presence of abundant quartz grains or grains not derived from exotic blocks (e.g., mudrock lithic clasts, 
K-feldspar grains, fossils). In the absence of the latter, the reasonable and less astonishing argument can be made that tectonic erosion of exotic blocks yields grains to the matrix, as the larger blocks are rounded during tectonic movements. Inasmuch as most outcrops and microfabric images show penetrative anisotropic fabrics, a tectonic origin following the view of Bero [55] is favored here.

A tectonic origin is also favored by the sum of the features present in the rocks. The Ring Mountain Mélange exhibits 14 of 16 of the features common to tectonic mélanges, including all three of the diagnostic features. In contrast, the mélange has only has eight of 15 features characteristic of sedimentary mélanges, one of four features (rounding of clasts) considered diagnostic of sedimentary mélanges, and three of 13 features common to diapiric mélanges (Table 1). If the mélange had a sedimentary history, the subsequent tectonic history has nearly obliterated evidence of that sedimentary history.

\subsubsection{Other Mélanges}

The Laytonville Mélange and the Serpentinite Mélange of Redwood City are both mélanges for which origins different than those advocated by the reporting authors seem reasonable. The Laytonville Mélange may be an amalgamated mass of multiple units or a deformed mass in which duplication of the unit gives the appearance of greater thickness. The features of the Serpentinite Mélange of Redwood City suggest a tectonic, pre-diapirism history. In these cases, however, debates on the origins have not been fully developed in the literature.

Several other mélanges in the Franciscan Complex have been assigned sedimentary or tectonic origins. In most cases, only a few features have been used to decide on the origin. The comprehensive list of features now available for discriminating among mélange origins (Table 1) should be used to re-evaluate the origins of all mélanges not thoroughly studied.


Figure 8. Rounding of serpentinite clasts in mélanges and serpentinite broken formations. (A) A combination of jointing, weathering with exfoliation, and shear at the block boundary is producing rounded serpentinite masses in this serpentinite-matrix mélange block that originally had a phacoidal shape. Exposure is near Liberty Gulch in Marin County, California; $40 \mathrm{~cm}$ hammer provides scale. (B) Coarse-grained (foliated) glaucophane schist (gs) block in Ring Mountain Mélange. Note the concentric foliation of the block. A serpentinite breccia zone (br) occurs at the right side of the block within the serpentinite (sp), which totally surrounds the block in the plane of exposure. Red lines mark foliation planes within the glaucophane schist and shear-fracture planes within the surrounding serpentinite. See text for additional discussion. 


\section{Discussion and Conclusions}

Considering the information reviewed above, it is clear that, through careful analyses, individual mélanges can be distinguished from one another, and their origins can be revealed on the basis of mélange characteristics, such as kinds of exotic blocks, sizes of included blocks, nature of structures, and matrix composition. These features aid in determining specific processes of fragmentation and mixing in the formation of the mélange. Thus, the features of the mélange reveal its origin.

It is important to note here that there is convergence in the nature of some fabrics developed in sedimentary and tectonic mélanges, especially in shallow parts of subduction zones, where sediments are poorly consolidated ([27,116-118] and Figure 6 of [27]). Stratal disruption, development of boudinage, soft-sediment shears, and mixing are all reported within shallow levels of some accretionary complexes. Thus, the duality of origins of some features common to both sedimentary and tectonic mélanges creates challenges in assessing mélange-forming processes. Tectonic overprints that mask the primary diagnostic fabric of sedimentary and diapiric mélanges further complicate assessment of mélange origins.

The representative Franciscan mélanges evaluated here appear to have formed by either tectonic or sedimentary processes. This preliminary analysis does not support the view that most Franciscan mélanges are sedimentary in origin. While diapirism is known in accretionary settings [119], most California Coast Range mélanges with evidence of diapirism show evidence of re-mobilization and later intrusion rather than syn-accretionary syntectonic diapirism [109,120,121]. In general, mélanges assigned a tectonic origin have features matching 10 or more of the typical characteristics of such mélanges and two or three of the definitive features. Similarly, most mélanges reviewed here assigned a sedimentary origin also have a dominance of features currently accepted as representative of a sedimentary history $[2,15,27]$.

Unequivocal sedimentary mélanges with mudrock, sandstone-mudrock, and sandstone matrix materials are widely distributed within the Franciscan (accretionary) Complex. Although sedimentary serpentinite-matrix mélanges are known in the overlying forearc Great Valley Group [122,123], the serpentinite-matrix mélanges examined here lack features that make a compelling case for a sedimentary history. The most definitive features indicative of a sedimentary origin are (1) depositional to gradational contacts, particularly in relation to underlying units, (2) an interbedded stratigraphic setting, (3) rounded clasts, especially if those clasts have diverse characters and petrologic histories, and (4) in situ fossils. Some mélanges, such as the Crescent City Olistostrome, clearly exhibit most of the characteristic and defining features of sedimentary mélanges. Other mélanges previously assigned a sedimentary origin, such as the Ring Mountain Mélange, do not.

Tectonic mélanges are particularly characterized by sheared and deformed contacts, by the presence of S-C or P-R structures (or both), and by scaly microfabrics, especially where those are accompanied by microbreccia and pseudotachylite. Mélanges such as the Rodeo Cove Mélange and the Ingram Canyon Mélange not only display the three definitive features of tectonic mélanges, they also have most other features found in mélanges of that origin. Clearly, they have a tectonic history.

Given that the accretionary complexes form in dynamic interplate settings, it is not surprising that most Franciscan mélanges have numerous tectonic features (Table 1). In sedimentary mélanges, these are superimposed on the sedimentary features, and it is clearly the case that even those Franciscan mélanges with definitive sedimentary histories exhibit some tectonically generated features (Table 1). It is possible that, in some cases, evidence of an early sedimentary history has been obscured or obliterated entirely by later post-formation tectonism. In the most extreme of such cases, we are left with no recourse other than to describe only the tectonic history. Arguments that a particular mélange had an early sedimentary history should be supported by at least two or more features that establish a compelling case for such a history. Since rounding of clasts may result from a variety of processes, rounded clasts by themselves do not make a compelling case for a sedimentary history.

Table 2 and the published literature reveal that mélanges of all origins may have either a petrologically limited or a diverse set of clasts, blocks, and phacoids. Clearly, that is true of Franciscan 
mélanges. In general, native clasts of sandstone are the most common. OPS fragments are ubiquitous as well and are present in every mélange evaluated in this review. High-grade glaucophane schists, however, while widely distributed, are not abundant. Fragments such as granitoid clasts, marbles, limestones, and mica schists are relatively sparsely distributed to rare.

Since clasts, blocks, and phacoids of diverse character apparently occur in both tectonic and sedimentary Franciscan mélanges, block content alone is not indicative of mélange origins. Block size also fails as a discriminator between sedimentary and tectonic mélanges. A definitive study of mélanges such as the Garzas Mélange and the Ingram Canyon Mélange that lie structurally adjacent to and immediately beneath eroded upper plate Coast Range Ophiolite (CRO) rocks to determine if these mélanges and the enclosed large and small upper plate blocks are the product of tectonic erosion would be useful and illuminating.

Additional studies of Franciscan mélanges, especially more studies including fabric and structural analyses, will further our understanding of Franciscan Complex architecture. Both the group of mélanges reviewed here and the larger group of remaining Franciscan mélanges would benefit from further study. Table 1 might be used as a beginning point in directing future studies. Clarifying the relationship of Franciscan mélanges to other architectural units of the accretionary complex will also aid in our understanding of overall subduction accretionary complex architecture. Ultimately, an understanding of the roles of mélanges in the archtypical Franciscan (subduction accretionary) Complex will allow use of the Franciscan mélanges and their relationships to serve as a guide to understanding other subduction accretionary complexes.

Funding: This research received no external funding.

Acknowledgments: I thank Kei Ogata for his invitation to participate in this mélange volume and for his continuing work on mélanges, which contributes to the overall advancement of the sub-science of mélange studies. Over the past five decades, chronologically, colleagues who especially and freely shared their ideas on mélanges with me and contributed to my understanding of and work on mélanges include Jim Berkland, Darrell Cowan, John Suppe, William Bosworth, Mark Cloos, Kees DeJong, Greg Horne, Tom Terranova, Ken Aalto, Marshall Maddock, Casey Moore, W.R. Brown, Marg McKinney, Ben Page, Al Lacazette, Nick Rast, Wright Horton, Mike Higgins, Jim Tull, John Wakabayashi, Gian Andrea Pini, Andrea Festa, Yujiro Ogawa, and David Bero. Appalachian State University Department of Geology, notably in the years of leadership by Fred Webb, Jr., provided support for my continuing efforts. I thank all of these individuals, each of whom may not agree with my ideas, but all of whom has shared his or her own perspective and/or helped me in my work. Two anonymous reviewers are thanked for their useful comments.

Conflicts of Interest: The author declares no conflict of interest.

\section{References}

1. Ernst, W.G. Accretion of the Franciscan Complex attending Jurassic-Cretaceous geotectonic development of northern and central California. Geol. Soc. Am. Bull. 2011, 123, 1667-1678. [CrossRef]

2. Raymond, L.A. What is Franciscan?: Revisited. Int. Geol. Rev. 2017, 60, 1968-2030. [CrossRef]

3. Wakabayashi, J. Anatomy of a subduction complex: Architecture of the Franciscan Complex, California, at multiple length and time scales. Int. Geol. Rev. 2015, 57, 669-746. [CrossRef]

4. Aalto, K.R. Multistage mélange formation in the Franciscan Complex, northernmost California. Geology 1981, 9, 602-607. [CrossRef]

5. Berkland, J.O.; Raymond, L.A.; Kramer, J.C.; Moores, E.M.; O’Day, M. What is Franciscan? Am. Assoc. Pet. Geol. Bull. 1972, 56, 2295-2302.

6. Aalto, K.R. Examples of Franciscan Complex mélanges in the northernmost California Coast Ranges, a retrospective. Int. Geol. Rev. 2014, 56, 555-570. [CrossRef]

7. Bero, D.A. Geology map of the western portion of the Jenner Headlands. In Jenner Headlands Integrated Management Plan; Edwards, B.R., Chestnut, A., Eds.; Sonoma Land Trust: Santa Rosa, CA, USA, 2012; The Wildlands Conservancy: Oak Glen, CA, USA, 2010.

8. Cloos, M. Flow mélanges: Numerical modeling and geologic constraints on their origin in the Franciscan subduction complex, California. Geol. Soc. Am. Bull. 1982, 93, 330-345. [CrossRef] 
9. Cloos, M.; Shreve, R.L. Subduction channel model of prism accretion, mélange formation, sediment subduction, and subduction erosion at convergent plate margins: 1. Background and description. Pure Appl. Geophys. 1988, 128, 455-500. [CrossRef]

10. Cloos, M.; Shreve, R.L. Subduction channel model of prism accretion, mélange formation, sediment subduction, and subduction erosion at convergent plate margins: 2. Implications and description. Pure Appl. Geophys. 1988, 128, 501-545. [CrossRef]

11. Cowan, D.S. Deformation and metamorphism of the Franciscan subduction zone complex northwest of Pacheco Pass, California. Geol. Soc. Am. Bull. 1974, 85, 1623-1634. [CrossRef]

12. Cowan, D.S. Origin of blueschist-bearing chaotic rocks in the Franciscan Complex, San Simeon, California. Geol. Soc. Am. Bull. 1978, 89, 1415-1423. [CrossRef]

13. Cowan, D.S. Structural styles in Mesozoic and Cenozoic mélanges in the western Cordillera of North America. Geol. Soc. Am. Bull. 1985, 96, 451-462. [CrossRef]

14. Ernst, W.G. Franciscan mélanges: Coherent blocks in a low-density, ductile matrix. Int. Geol. Rev. 2016, 58, 626-642. [CrossRef]

15. Festa, A.; Pini, G.A.; Dilek, Y.; Codegone, G. Mélanges and mélange-forming processes: A historical overview and new concepts. Int. Geol. Rev. 2010, 52, 1040-1105. [CrossRef]

16. Hsu, K.J. Principles of mélanges and their bearing on the Franciscan-Knoxville paradox. Geol. Soc. Am. Bull. 1968, 79, 1063-1074. [CrossRef]

17. Hsu, K.J. Preliminary Report and Geologic Guide to Franciscan Mélanges of the Morrow Bay-San Simeon Area California; California Division of Mines and Geology: Sacramento, CA, USA, 1969; Publication 35; 46p.

18. Raymond, L.A. Tectonite and mélange-A distinction. Geology 1975, 3, 7-9. [CrossRef]

19. Raymond, L.A. Perspectives on the roles of mélanges in subduction accretionary complexes: A review. Gondwana Res. 2019. [CrossRef]

20. Wakabayashi, J. Mélanges of the Franciscan complex, California: Diverse structural settings, evidence for sedimentary mixing, and their connection to subduction processes. In Mélanges: Processes of Formation and Societal Significance; Wakabayashi, J., Dilek, Y., Eds.; Special Paper 480; Geological Society of America: Boulder, CO, USA, 2011; pp. 117-141.

21. Raymond, L.A. Classification of Mélanges. In Mélanges: Their Nature, Origin, and Significance; Raymond, L.A., Ed.; Special Paper 198; Geological Society of America: Boulder, CO, USA, 1984; pp. 7-20.

22. Silver, E.A.; Beutner, E.C. Mélanges. Geology 1980, 8, 32-34. [CrossRef]

23. Meneghini, F.; Moore, J.C. Deformation and hydrofracture in a subduction thrust at seismogenic depths: Rodeo Cove thrust zone, Marin Headlands, California. Geol. Soc. Am. Bull. 2007, 119, 174-183. [CrossRef]

24. Ogata, K.; Pini, G.A.; Tinterri, R.; Mutti, E. Mass transport processes and related deformation mechanisms in sedimentary mélanges. Soc. Geol. Ital. 2012, 22, 158-161.

25. Orange, D. Criteria helpful in recognizing shear-zone and diapiric mélanges: Examples from the Hoh accretionary complex, Olympic Peninsula, Washington. Geol. Soc. Am. Bull. 1990, 102, 935-951. [CrossRef]

26. Festa, A.; Dilek, Y.; Pini, G.A.; Codegone, G.; Ogata, K. Mechanisms and processes of stratal disruption and mixing in the development of mélanges and broken formations: Redefining and classifying mélanges. Tectonophysics 2012, 568, 7-24. [CrossRef]

27. Festa, A.; Pini, G.A.; Ogata, K.; Dilek, Y. Diagnostic features and field-criteria in recognition of tectonic, sedimentary and diapiric mélanges in orogenic belts and exhumed subduction-accretion complexes. Gondwana Res. 2019. [CrossRef]

28. Gucwa, P.R. Geology of the Covelo/Laytonville Area, Northern California. Ph.D. Thesis, University of Texas, Austin, TX, USA, 1974; 82p.

29. Raymond, L.A. Petrology: The Study of Igneous, Sedimentary, and Metamorphic Rocks; Wm. C. Brown Publishers: Dubuque, IA, USA, 1995; 742p.

30. Jeanbourquin, P. Chronology of deformation of a Franciscan mélange near San Francisco, (California, USA). Ecol. Geol. Helv. 2000, 93, 363-378.

31. O'Hanley, D.S. Serpentinites: Records of Tectonic and Petrological History; Oxford University Press: New York, NY, USA, 1996; 277p.

32. Raymond, L.A.; Bero, D.A. Sandstone-matrix mélanges, architectural subdivision, and geologic history of accretionary complexes: A sedimentological and structural perspective from the Franciscan complex of Sonoma and Marin counties, California, USA. Geosphere 2015, 11, 1-34. [CrossRef] 
33. Wakabayashi, J. Subducted sedimentary serpentinite mélanges: Record of multiple burial-exhumation cycles and subduction erosion. Tectonophysics 2012, 568-569, 230-247. [CrossRef]

34. Aalto, K.R. Franciscan Complex olistostrome at Crescent City, northern California. Sedimentology 1989, 36, 471-495. [CrossRef]

35. Aalto, K.R. Sandstone petrology and tectonostratigraphic terranes of the northwest California and southwest Oregon Coast Ranges. J. Sediment. Petrol. 1989, 59, 561-571. [CrossRef]

36. Aalto, K.R. Franciscan depositional setting based on early-formed structures in debris flow deposits and turbidites, Point St. George, northern California. In Conglomerates in Basin Analysis; Colburn, I., Abbott, P., Minch, J., Eds.; Pacific Section, Society of Economic Paleontologists and Mineralogists: Los Angeles, CA, USA, 1989; Book 62; pp. 169-178.

37. Aalto, K.R.; Murphy, J.M. Franciscan Complex Geology of the Crescent City area, northern California. In Franciscan Geology of Northern California; Blake, M.C., Jr., Ed.; Pacific Section, Society of Economic Paleontologists and Mineralogists: Los Angeles, CA, USA, 1989; Book 43; pp. 185-201.

38. Aalto, K.R. Depositional sequence of argillite, diamictite, hyaloclastite, and lava flows within the Franciscan Complex, northern California. J. Geol. 1986, 94, 744-752. [CrossRef]

39. Jayko, A.S.; Blake, M.C., Jr.; McLaughlin, R.J.; Ohlin, H.N.; Ellen, S.D.; Kelsey, H. Reconnaissance Geologic Map of the Covelo 30- by 60-Minute Quadrangle, Northern California; U.S. Geological Survey Geological Survey Miscellaneous Field Studies Map MF-2001, Scale 1:100,000; U.S. Geological Survey: Washington, DC, USA, 1989.

40. Kleist, J. Geology of the Coastal Belt, Franciscan Complex, Near Ft. Bragg, California. Ph.D Thesis, University of Texas, Austin, TX, USA, 1974; 133p.

41. Erikson, R. Petrology of a Franciscan olistostrome with a massive sandstone matrix: The King Ridge Road Mélange at Cazadero, California. In Mélanges: Processes of Formation and Societal Significance; Wakabayashi, J., Ed.; Special Paper 480; Geological Society of America: Boulder, CO, USA, 2011; pp. 171-188.

42. Raymond, L.A.; (Sonoma State University, Rohnert Park, CA, USA). New Unpublished Data. 2019.

43. Wakabayashi, J. Subduction Initiation, Subduction Accretion, and Nonaccretion, Large-Scale Material Movement, and Localization of Subduction Megaslip Recorded in Franciscan Complex and Related Rocks, California; Field Guide 32; Geological Society of America: Boulder, CO, USA, 2013; pp. 129-162. [CrossRef]

44. Wakabayashi, J.; Rowe, C.D. Whither the megathrust? Localization of large-scale subduction slip along the contact of a mélange. Int. Geol. Rev. 2015, 57, 854-870. [CrossRef]

45. Raymond, L.A. Designating tectonostratigraphic terranes versus mapping rock units in subduction complexes: Perspectives from the Franciscan Complex of California, USA. Int. Geol. Rev. 2015, 57, 801-823. [CrossRef]

46. Raymond, L.A.; Ogawa, Y.; Maddock, M.E. Accretionary unit formats in subduction complexes: Examples from the Miura-Boso and Franciscan complexes. Int. Geol. Rev.. Under review.

47. Raymond, L.A.; Ogawa, Y.; Maddock, M.E. Evaluating Subduction Accretionary Complex Architecture and History: Accretionary Unit Types from the Franciscan and Miura-Boso Complexes. In Proceedings of the GSA Cordilleran Section Meeting, Portland, OR, USA, 15-17 May 2019. Talk 29-3.

48. Raymond, L.A. Franciscan Geology of the Mt. Oso Area, Central California. Ph.D. Thesis, University of California, Davis, CA, USA, 1973; 185p.

49. Maddock, M.E. Geology of the Mt. Boardman Quadrangle, Santa Clara and Stanislaus Counties, California; California Division of Mines and Geology Map Sheet 3, Scale 1:62500; California Division of Mines and Geology: Sacramento, CA, USA, 1964.

50. Wahrhaftig, C. Structure of the Marin Headlands Block, California: A progress report. In Franciscan Geology of Northern California; Blake, M.C., Jr., Ed.; Pacific Section, Society of Economic Paleontologists and Mineralogists: Los Angeles, CA, USA, 1989; Book 43; pp. 31-50.

51. Meneghini, F.; Marroni, M.; Moore, J.C.; Pandolfi, L.; Rowe, C.D. The processes of underthrusting and underplating in the geologic record: Structural diversity between the Franciscan Complex (California), the Kodiak Complex (Alaska) and the Internal Ligurian Units (Italy). Geol. J. 2009, 44, 126-152. [CrossRef]

52. Errico, J.C.; Barnes, J.D.; Strickland, A.; Valley, J.W. Oxygen isotope zoning in garnets from Franciscan eclogite blocks: Evidence for rock-buffered fluid interaction in the mantle wedge. Contrib. Mineral. Petrol. 2013, 166, 1161-1176. [CrossRef] 
53. Raymond, L.A. A metasomatic setting, the Russian River Arch, and gravitational emplacement in the history of eclogites at the classic eclogite locality of Jenner, California, USA. Int. Geol. Rev. 2017, 59, 577-598. [CrossRef]

54. Wakabayashi, J. Contrasting settings of serpentinite bodies, San Francisco Bay Area, California: Derivation from the subducting plate vs. mantle hanging wall? Int. Geol. Rev. 2004, 46, 1103-1118. [CrossRef]

55. Bero, D.A. Geology of Ring Mountain and Tiburon Peninsula, Marin County, California; California Geological Survey Map Sheet 60 [with text], Scales 1:12:000 and 1:6000, 2 Sheets; California Geological Survey: Sacramento, CA, USA, 2014; 35p.

56. Ha, Y.; Jung, H.; Raymond, L.A. Deformation fabrics of glaucophane schists and implications for seismic anisotropy: The importance of lattice preferred orientation of phengite. Int. Geol. Rev. 2019, 61, 720-737. [CrossRef]

57. Uno, M.; Kirby, S. Evidence for multiple stages of serpentinization from the mantle through the crust in the Redwood City Serpentinite mélange along the San Andreas Fault in California. Lithos 2019, 336-337, 276-292. [CrossRef]

58. Mutti, E.; Ricci-Lucchi, F. Turbidites of the Northern Apennines: Introduction to Facies Analysis; A.G.I. Reprint Series 3; First Published in 1972; American Geological Institute: Falls Church, VA, USA, 1978; pp. 125-166.

59. Dumitru, T.A.; Ernst, W.G.; Hourigan, J.K.; McLaughlin, R.J. Detrital zircon U-Pb reconnaissance of the Franciscan subduction complex in northwestern California. Int. Geol. Rev. 2015, 57, 567-800. [CrossRef]

60. Gucwa, P.R. Middle to Late Cretaceous sedimentary mélange, Franciscan Complex, northern California. Geology 1975, 3, 105-108. [CrossRef]

61. Alvarez, W.; Kent, D.V.; Silva, I.P.; Schweickert, R.A.; Larson, R.A. Franciscan Complex limestone deposited at $17^{\circ}$ South latitude. Geol. Soc. Am. Bull. 1980, 91, 476-484. [CrossRef]

62. Wood, R.M. The Laytonville Quarry (Mendocino County California) exotic block: Iron-rich blueschist-facies subduction-zone metamorphism. Mineral. Mag. 1982, 45, 87-99. [CrossRef]

63. Cowan, D.S.; Page, B.M. Recycled Franciscan mélange west of Paso Robles, California. Geol. Soc. Am. Bull. 1975, 86, 1089-1095. [CrossRef]

64. Moore, D.E.; Liou, J.G. Detrital glaucophane schist pebbles from Franciscan metaconglomerates of the northeast Diablo Range, California. Am. J. Sci. 1980, 280, 249-264. [CrossRef]

65. Chapman, A.D.; Jacobson, C.E.; Ernst, W.G.; Grove, M.; Dumitru, T.; Hourigan, J.; Ducea, M.H. Assembling the world's type shallow subduction complex: Detrital zircon geochronologic constraints on the origin of the Nacimiento block, central California Coast Ranges. Geosphere 2016, 12, 533-557. [CrossRef]

66. Dumitru, T.A.; Elder, W.P.; Hourigan, J.K.; Chapman, A.D.; Graham, S.A.; Wakabayashi, J. Four Cordilleran paleorivers that connected Sevier thrust zones in Idaho to depocenters in California, Washington, Wyoming, and, indirectly, Alaska. Geology 2016, 44, 75-78. [CrossRef]

67. Dumitru, T.A.; Hourigan, J.K.; Elder, W.P.; Ernst, W.G.; Joesten, R. New, much younger ages for the Yolla Bolly terrane and a revised time line for accretion in the Franciscan subduction complex, California. In Tectonics, Sedimentary Basins, and Provenance: A Celebration of the Career of William R. Dickinson; Ingersoll, R.V., Lawton, T.F., Graham, S.A., Eds.; Special Paper 540; Geological Society of America: Boulder, CO, USA, 2018; pp. 339-366. [CrossRef]

68. Greene, T.J.; Surpless, K.D. Facies architecture and provenance of a boulder-conglomerate submarine channel system, Panoche Formation, Great Valley Group: A forearc basin response to middle Cretaceous tectonism in the California convergent margin. Geosphere 2017, 13. [CrossRef]

69. Jacobson, C.E.; Grove, M.; Pedrick, J.N.; Barth, A.P.; Marsaglia, K.M.; Gehrels, G.E.; Nourse, J.A. Late Cretaceous-early Cenozoic tectonic evolution of the southern California margin inferred from provenance of trench and forearc sediments. Geol. Soc. Am. Bull. 2011, 123, 485-506. [CrossRef]

70. Paterson, S.R.; Memeti, V.; Anderson, L.; Cao, W.; Lackey, J.S.; Putirka, K.D.; Miller, R.B.; Miller, J.S.; Mundil, R. Day 6: Overview of arc processes and tempos. In Formation of the Sierra Nevada Batholith: Magmatic and Tectonic Processes and Their Tempos; Memeti, V., Paterson, S.R., Putirka, K.D., Eds.; Field Guide 34; Geological Society of America: Boulder, CO, USA, 2014; pp. 87-116. [CrossRef]

71. Sharman, G.R.; Graham, S.A.; Grove, M.; Kimbrough, D.L.; Wright, J.E. Detrital zircon provenance of the Late Cretaceous-Eocene California forearc: Influence of Laramide low-angle subduction on sediment dispersal and paleogeography. Geol. Soc. Am. Bull. 2015, 127, 38-60. [CrossRef] 
72. Bailey, E.H.; Irwin, W.P.; Jones, D.L. Franciscan and Related Rocks, and their Significance in the Geology of Western California; Bulletin 183; California Division of Mines and Geology: San Francisco, CA, USA, 1964; 177p.

73. Wagner, D.L.; Bortugno, E.J.; McJunkin, R.D. Geologic Map of the San Francisco-San Jose Quadrangle, California, 1:250,000; California Division of Mines and Geology: San Francisco, CA, USA, 1990.

74. Blake, M.C., Jr.; Jones, D.L. Origin of Franciscan mélanges in northern California. In Modern and Ancient Geosynclinal Sedimentation; Dott, R.H., Jr., Shaver, R.H., Eds.; Special Publication Number 19; Society of Economic Paleontologists and Mineralogists: Tulsa, OK, USA, 1974; pp. 345-357.

75. Blake, M.C., Jr.; Jones, D.L. The Franciscan assemblage and related rocks in northern California: A reinterpretation. In The Geotectonic Development of California; Ernst, W.G., Ed.; Prentice-Hall, Inc.: Englewood Cliffs, NJ, USA, 1981; pp. 307-328.

76. Cloos, M. Flow mélanges and the structural evolution of accretionary wedges. In Mélanges: Their Nature, Origin, and Significance; Raymond, L.A., Ed.; Special Paper 198; Geological Society of America: Boulder, CO, USA, 1984; pp. 71-79.

77. Cloos, M. Blueschists in the Franciscan Complex of California: Petrotectonic constraints on uplift mechanisms. In Blueschists and Eclogites; Evans, B.W., Brown, E.H., Eds.; Memoir 164; Geological Society of America: Boulder, CO, USA, 1986; pp. 77-93.

78. Hamilton, W.B. Mesozoic California and the underflow of Pacific mantle. Geol. Soc. Am. Bull. 1969, 80, 2409-2430. [CrossRef]

79. Hamilton, W. Subduction in the Indonesian region. In Island Arcs Deep Sea Trenches and Back-Arc Basins; Talwani, M., Pitman, W.C., III, Eds.; Maurice Ewing Series Vol. 1; American Geophysical Union: Washington, DC, USA, 1977; pp. 15-31.

80. Aalto, K.R. Sedimentology of a mélange: Franciscan of Trinidad, California. J. Sediment. Petrol. 1976, 46, 913-929. [CrossRef]

81. Maxwell, J.C. Anatomy of an orogen. Geol. Soc. Am. Bull. 1974, 85, 1195-1204. [CrossRef]

82. MacPherson, G.J.; Phipps, S.P.; Grossman, J.N. Diverse sources for igneous blocks in Franciscan mélanges, California Coast Ranges. J. Geol. 1990, 98, 845-862. [CrossRef]

83. MacPherson, G.J.; Giaramita, M.J.; Phipps, S.P. Tectonic implications of diverse igneous blocks in Franciscan mélange, northern California and southwestern Oregon. Am. Mineral. 2006, 91, 1509-1520. [CrossRef]

84. Bedrossian, T.L. Geology of the Marin Headlands. Calif. Geol. 1974, 27, 75-86.

85. Raymond, L.A. Tesla-Ortigalita fault, Coast Range thrust fault, and Franciscan metamorphism, northeastern Diablo Range, California. Geol. Soc. Am. Bull. 1973, 84, 3547-3562. [CrossRef]

86. Wentworth, C.M.; Blake, M.C., Jr.; McLaughlin, R.J.; Graymer, R.W. Geologic Map of the San Jose 30 X 60-Minute Quadrangle, Calfiornia; U.S. Geological Survey Open File Report 98-795; U.S. Geological Survey: Washington, DC, USA, 1999; Part 7.

87. Raymond, L.A. Retracing Post-Subduction History: A Preliminary Palinspastic and Pseudo-Palinspastic Reconstruction of Pre-Pliocene Franciscan Complex Architecture, Northeastern Diablo Range, California. In Proceedings of the GSA Cordilleran Section Meeting, Portland, OR, USA, 15-17 May 2019. Talk 17-8.

88. Harms, T.; Jayko, A.S.; Blake, M.C., Jr. Kinematic evidence for extensional unroofing of the Franciscan Complex along the Coast Range Fault, northern Diablo Range, California. Tectonics 1992, 11, $228-241$. [CrossRef]

89. Clift, P.D.; Hartley, A.D. Slow rates of subduction-erosion and coastal underplating along the Andean margin of Chile and Peru. Geology 2007, 35, 503-506. [CrossRef]

90. Clift, P.; Vannucchi, P. Controls on tectonic accretion versus erosion in subduction zones: Implications for the origin and recycling of the continental crust. Rev. Geophys. 2004, 42. [CrossRef]

91. Escuder-Virente, J.; Baumgartner, P.O. Structural evolution and deformation kinematics of a subduction related serpentinite-matrix mélange, Santa Elena peninsula, northwest Costa Rica. J. Struct. Geol. 2014, 66, 356-381. [CrossRef]

92. Page, B.M. Time of completion of underthrusting of Franciscan beneath Great Valley rocks west of Salinian block, California. Geol. Soc. Am. Bull. 1970, 83, 957-972. [CrossRef]

93. Page, B.M. Oceanic crust and mantle fragment in subduction complex near San Luis Obispo, California. Geol. Soc. Am. Bull. 1972, 83, 957-972. [CrossRef]

94. Von Huene, R.; Scholl, D.W. Observations at convergent margins concerning sediment subduction, subduction erosion, and the growth of continental crust. Rev. Geophys. 1991, 29, 279-316. [CrossRef] 
95. Delattre, M.P.; Koehler, R.D. Geologic Map of the Camp Meeker 7.5" Quadrangle, Sonoma County, California: Scale 1:24000, One Sheet; California Geological Survey: Sacramento, CA, USA, 2009.

96. Blake, M.C., Jr.; Graymer, R.W.; Stamski, R.E. Geologic Map and Map Database of Western Sonoma, Northernmost Marin, and Southernmost Mendocino Counties, California, version 1.0; U.S. Geological Survey Miscellaneous Field Studies Map MF-2402, Scale 1:100000, 1 Sheet; U.S. Geological Survey: Washington, DC, USA, 2002; 43p.

97. Blake, M.C., Jr.; Smith, J.T.; Wentworth, C.M.; Wright, R.H. Preliminary Geologic Map of Western Sonoma County and Northernmost Marin County, California; U.S. Geological Survey Open File Map, Scale 1:62500; U.S. Government Printing Office: Washington, DC, USA, 1971.

98. Raymond, L.A.; Christensen, W.P. Petrographic reconnaissance of Franciscan rocks, Occidental-Guerneville area, Sonoma County, California. In Geologic Guide to the Northern Coast Ranges-Point Reyes Region, California; Moores, E.M., Matthews, R.A., Eds.; Annual Field Trip Guide of the Geological Society of Sacramento; California Division of Mines and Geology: Sacramento, CA, USA, 1971; pp. 38-46.

99. Raymond, L.A. The polygenetic Heaven's Beach Mélange, Franciscan Complex, California, USA. In Proceedings of the Geological Society of America Annual Meeting, Seattle, WA, USA, 22-25 October 2017. Abstract 322-1.

100. Krogh, E.J.; Oh, C.W.; Liou, J.G. Polyphase and anticlockwise P-T evolution for Franciscan eclogites and blueschists from Jenner, California USA. J. Metamorph. Geol. 1994, 12, 121-134. [CrossRef]

101. Mulcahy, S.R.; Beaudoin, G.M. The eclogite to blueschist transition in Franciscan metabasites. Geol. Soc. Am. Abstr. Programs 2015, 47, 775.

102. Crawford, K.E. Reconnaissance Geologic Map of the Eylar Mountain Quadrangle, Santa Clara and Alameda Counties, California; U.S. Geological Survey Miscellaneous Field Studies Map MF-764, Scale 1:24000, 1 Sheet; U.S. Geological Survey: Washington, DC, USA, 1976.

103. Schlocker, J. Geology of the San Francisco North Quadrangle, California; U.S. Professional Paper 782; U.S. Geological Survey: Washington, DC, USA, 1974; 104p.

104. Bonilla, M.G. Preliminary Geologic Map of He San Francisco South 7.5' Quadrangle and Part of the Hunters Point 7.5' Quadrangle, San Francisco Bay Area, California; U.S. Geological Survey Open-File Report 98-354, Scale 1:24000; U.S. Geological Survey: Washington, DC, USA, 1998.

105. Wakabayashi, J. Counterclockwise P-T-t paths from amphibolites, Franciscan Complex, California: Relics from the early stages of subduction zone metamorphism. J. Geol. 1990, 98, 657-680. [CrossRef]

106. Becker, D.G.; Cloos, M. Mélange diapirs into the Cambria slab: A Franciscan trench slope basin near Cambrian, California. J. Geol. 1985, 93, 101-110. [CrossRef]

107. Ogawa, Y.; Mori, R.; Tsunogae, T.; Dilek, Y.; Harris, R. New interpretation of the Franciscan mélange at San Simeon coast, California: Tectonic intrusion into an accretionary prism. Int. Geol. Rev. 2015, 57, 824-842. [CrossRef]

108. Pampeyan, E.H. Geologic Map of the Palo Alto and part of the Redwood Point 7-1/2' quadrangles, San Mateo and Santa Clara Counties, California; U.S. Geological Survey [text to accompany] Map I-2371; U.S. Geological Survey: Washington, DC, USA, 1993; 28p.

109. Page, B.M.; De Vito, L.A.; Coleman, R.G. Tectonic emplacement of serpentinite southeast of San Jose, California. Int. Geol. Rev. 1999, 41, 494-505. [CrossRef]

110. Anczkiewicz, B.; Platt, J.P.; Thirlwall, M.F.; Wakabayashi, J. Franciscan subduction off to a slow start: Evidence from high-precision Lu-Hf garnet ages on high grade-blocks. Earth Planet. Sci. Lett. 2004, 225, 147-161. [CrossRef]

111. Dudley, P.P. Glaucophane Schists and Associated Rocks of the Tiburon Peninsula, Marin County, California. Ph.D. Thesis, University of California, Berkeley, CA, USA, 1967; 116p.

112. Dudley, P.P. Comments on the distribution and age of high-grade blueschists, associated eclogites, and amphibolites from the Tiburon Peninsula, California. Geol. Soc. Am. Bull. 1969, 83, 3497-3500. [CrossRef]

113. Mulcahy, S.R.; King, R.L.; Vervoort, J.D. Lawsonite Lu-Hf geochronology: A new geochronometer for subduction zone processes. Geology 2009, 37, 987-990. [CrossRef]

114. Tsujimori, T.; Matsumoto, K.; Wakabayashi, J.; Liou, J.G. Franciscan eclogite revisited: Reevaluation of the P-T evolution of tectonic blocks from Tiburon Peninsula, California, U.S.A. Mineral. Petrol. 2006, 88, $243-267$. [CrossRef]

115. Page, N.J. Serpentinization in a Sheared Serpentinite Lens, Tiburon Peninsula, California; U.S. Geological Survey Professional Paper 600; U.S. Geological Survey: Washington, DC, USA, 1968; pp. B21-B28. 
116. Aalto, K.R. The Franciscan Complex of northernmost California: Sedimentation and tectonics. In Trench-Forearc Geology: Sedimentations and Tectonics on Modern and Ancient Active Plate Margins; Leggett, J.K., Ed.; The Geological Society of London Special Publication 10; Blackwell Scientific Publications: Oxford, UK, 1982; pp. 419-432.

117. Ogata, K.; Festa, A.; Pini, G.A.; Pogačnik, Ž.; Lucente, C.C. Substrate deformation and incorporation in sedimentary mélanges (olistostromes): Examples from the northern Apennines (Italy) and northwestern Dinarides (Slovenia). Gondwana Res. 2019. [CrossRef]

118. Moore, J.C.; Cowan, D.S.; Karig, D.E. Structural styles and deformation fabrics of accretionary complexes. Geology 1985, 77-79. [CrossRef]

119. Maekawa, H.; Shozui, M.; Ishii, T.; Saboda, K.L.; Ogawa, Y. Metamorphic rocks from the serpentinite seamounts in the Izu-Ogasawara forearcs. Proc. Ocean. Drill. Program. 1992, 125, 415-430.

120. Dickinson, W.R. Table Mountain serpentinite extrusion in California Coast Ranges. Geol. Soc. Am. Bull. 1966, 77, 451-472. [CrossRef]

121. Tsujimori, T.; Liou, J.G.; Coleman, R.G. Finding high-grade tectonic blocks from the New Idria serpentinite body, Diablo Range, California: Petrologic constraints on the tectonic evolution of an active serpentinite diapir. In Convergent Margin Terranes and Associated Regions: A Tribute to W.G. Ernst; Cloos, M., Carlson, W.D., Gilbert, M.C., Liou, J.G., Sorenson, S.S., Eds.; Special Paper 419; Geological Society of America: Boulder, CO, USA, 2007; pp. 67-80.

122. Moiseyev, A.N. Late serpentinite movements in the California Coast Ranges: New evidence and its implications. Geol. Soc. Am. Bull. 1970, 81, 1721-1732. [CrossRef]

123. Wakabayashi, J. Sedimentary serpentinite and chaotic units of the lower Great Valley Group forearc basin deposits, California: Updates on distribution and characteristics. Int. Geol. Rev. 2017, 59, 599-620. [CrossRef]

(C) 2019 by the author. Licensee MDPI, Basel, Switzerland. This article is an open access article distributed under the terms and conditions of the Creative Commons Attribution (CC BY) license (http://creativecommons.org/licenses/by/4.0/). 